Article

\title{
Synthesis of New GABA Receptor Modulator with Pyrazolo[1,5-a]quinazoline (PQ) Scaffold
}

\author{
Gabriella Guerrini ${ }^{1, *} \mathbb{C}$, Claudia Vergelli ${ }^{1}$, Niccolò Cantini ${ }^{1}$, Maria Paola Giovannoni ${ }^{1} \oplus$,

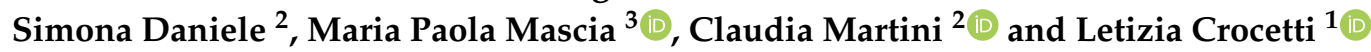 \\ 1 Dipartimento Neurofarba, sezione Farmaceutica e Nutraceutica, Università di Firenze, Via Ugo Schiff 6, \\ Sesto Fiorentino, 50019 Firenze, Italy; claudia.vergelli@unifi.it (C.V.); niccolo.cantini@unifi.it (N.C.); \\ mariapaola.giovannoni@unifi.it (M.P.G.); letizia.crocetti@unifi.it (L.C.) \\ 2 Dipartimento di Farmacia, Università di Pisa, Via Bonanno 6, 56126 Pisa, Italy; \\ simona.daniele@unipi.it (S.D.); claudia.martini@unipi.it (C.M.) \\ 3 CNR-Institute of Neuroscience, Cagliari, Cittadella Universitaria, 09042 Monserrato, Italy; \\ mariapaola.mascia@cnr.it \\ * Correspondence: gabriella.guerrini@unifi.it
}

Received: 4 February 2019; Accepted: 14 March 2019; Published: 21 March 2019

\begin{abstract}
We previously published a series of 8-methoxypirazolo[1,5-a]quinazolines (PQs) and their 4,5-dihydro derivatives $(4,5(H) \mathrm{PQ})$ bearing the (hetero)arylalkylester group at position 3 as ligands at the $\gamma$-aminobutyric type $\mathrm{A}\left(\mathrm{GABA}_{\mathrm{A}}\right)$ subtype receptor. Continuing the study in this field, we report here the design and synthesis of 3-(hetero)arylpyrazolo[1,5-a]quinazoline and 3-(hetero)aroylpyrazolo[1,5-a]quinazoline 8-methoxy substituted as interesting analogs of the above (hetero)arylalkylester, in which the shortening or the removal of the linker between the 3-(hetero)aryl ring and the PQ was performed. Only compounds that are able to inhibit radioligand binding by more than $80 \%$ at $10 \mu \mathrm{M}$ have been selected for electrophysiological studies on recombinant $\alpha 1 \beta 2 \gamma 2 \mathrm{~L} \mathrm{GABA}_{\mathrm{A}}$ receptors. Some compounds show a promising profile. For example, compounds $\mathbf{6 a}$ and $\mathbf{6 b}$ are able to modulate the $\mathrm{GABA}_{\mathrm{A}} \mathrm{R}$ in an opposite manner, since $\mathbf{6 b}$ enhances and $\mathbf{6 a}$ reduces the variation of the chlorine current, suggesting that they act as a partial agonist and an inverse partial agonist, respectively. The most potent derivative was 3-(4-methoxyphenylcarbonyl)-8-methoxy-4,5-dihydropyrazolo[1,5-a] quinazoline 11d, which reaches a maximal activity at $1 \mu \mathrm{M}(+54 \%)$, and it enhances the chlorine current at $\geq 0.01 \mu \mathrm{M}$. Finally, compound $6 \mathrm{~g}$, acting as a null modulator at $\alpha 1 \beta 2 \gamma 2 \mathrm{~L}$, shows the ability to antagonize the full agonist diazepam and the potentiation of CGS 9895 on the new $\alpha+/ \beta$ - 'non-traditional' benzodiazepine site.
\end{abstract}

Keywords: $\mathrm{GABA}_{\mathrm{A}}$ receptor; high affinity benzodiazepine site; low affinity benzodiazepine site; pyrazolo[1,5-a]quinazoline; organic synthesis; electrophysiological studies; Xenopus oocytes

\section{Introduction}

$\gamma$-aminobutyric type $A\left(G_{A B A}\right)$ receptors Type $A\left(G A B A_{A} R\right)$ and Type $B\left(G A B A_{B} R\right)$ are the principal inhibitory neurotransmitter receptors in the mammalian brain, and are the targets of many important drugs on the market for a variety of neurological conditions, including epilepsy, anxiety, spasticity, pain, and psychiatric illness [1]. The neurotransmitter GABA produces slow (sub-second) synaptic response by interaction with the $G_{A B A} R s$, belonging to the G-protein-coupled receptors (GPCR) category, or exerts fast ( $<10 \mathrm{~ms})$ and powerful synaptic inhibition by acting on the $\mathrm{GABA}_{\mathrm{A}} \mathrm{Rs}$, which is a Cys-loop pentameric ligand gated ion channel (LGIC). This last family of receptors also includes the nicotinic acetylcholine receptors (nAChRs), the 5-hydroxytriptamine type 3 receptors $\left(5-\mathrm{HT}_{3} \mathrm{Rs}\right)$, and the glycine receptors, all of which show a similar topology, namely five homologous 
subunits assembled to form a central ion-conducting pore. Each subunit is formed by an N-terminal extracellular domain (ECD), four $\alpha$-helices transmembrane domains (TM1-TM4), in which the TM2 of all the subunits is arranged to form the inner pore, and a C-terminal intracellular domain (ICD). To date, for the human $\mathrm{GABA}_{\mathrm{A}} \mathrm{R}, 19$ genes encoding the protein receptor have been sequenced and classified as different families, based on the degree of homology: $\alpha 1-6, \beta 1-3, \gamma 1-3, \delta, \varepsilon, \pi, \theta$, and $\rho 1-3$ [2]. Although the combination of all the subunits could contribute to form the pentamer, $\alpha$ and $\beta$ subunits are necessary to obtain a fully functional receptor. Subunit $\gamma$ contributes to form the most abundant $\mathrm{GABA}_{\mathrm{A}}$ receptor subtype in the central nervous system (CNS), which is composed by $2 \alpha 2 \beta 1 \gamma$ subunits. Depending on the subunit isoforms $(\alpha 1-6, \beta 1-3, \gamma 1-3)$ and regional brain distribution, each subtype receptor $(\alpha 1 \beta \gamma 2, \alpha 2 \beta \gamma 2, \alpha 3 \beta \gamma 2, \alpha 4 \beta \gamma 2, \alpha 5 \beta \gamma 2$, and $\alpha 5 \beta \gamma 2)$ modulates different brain functions, and in general, its expression at synaptic or extrasynaptic sites mediates phasic or tonic inhibition $[3,4]$. The $\delta$ subunit can co-exist with $\alpha \beta$ subunits to form a functional pentamer located exclusively extrasynaptically, or form the $\mathrm{GABA}_{\mathrm{A}} \mathrm{R}$ subtype that spontaneously opens the gate, even in the absence of a neurotransmitter $[5,6]$. The principal binding sites of $\mathrm{GABA}_{\mathrm{A}} \mathrm{R}$ are sited in the extracellular domain between two adjacent subunits; the first one is known as the "principal" (conventionally indicated with plus or + ), and the other one is called the "complementary" subunit (indicated with minus or -) [4]. Thus, the two orthosteric GABA binding sites are located at the $\alpha+/ \beta-$ interfaces, while the "benzodiazepine site" is located at the $\alpha+/ \beta-$ interface. Recently, a renewed search for GABA $A_{A} R$ has identified a new interaction site, which is similar to 'benzodiazepine site' and located at the homologous interface $(\alpha+/ \beta-)$ [7-9]. The $\alpha$ subunit of this site contains the same protein loop sequences of the principal 'benzodiazepine site $\alpha$ ' and, analogously to this latter, the six $\alpha$ isoforms and the three $\beta$ isoforms in concert contribute to form the binding site [9]. This $\alpha+/ \beta$ - 'non-traditional' benzodiazepine site was first described as the site for diazepam, which is able to produce a less specific GABA potentiation at micromolar concentration. The binding of diazepam at $\alpha+/ \beta-$ is independent of the $\gamma$ subunit, and it is insensible to flumazenil [10]. The first ligand discovered for this new site [11,12] was CGS 9895 (2-p-methoxyphenylpyrazolo[4,3-c]quinolin-3-(5H)-one), which is already known as a high affinity benzodiazepine site $(\alpha+/ \beta-)$ antagonist. CGS 9895 showed also the ability to enhance the GABA currents at the $\alpha+/ \beta$ - site, working as an agonist. Moreover, the binding to the low-affinity $\alpha+/ \beta-$ binding site is not strictly bound to antagonistic activity at the benzodiazepine site. In fact, in a previous work, it has been demonstrated that also lorazepam and the imidazopyridine zolpidem in $\mathrm{GABA}_{\mathrm{A}}$ receptors devoid of the $\gamma$ subunit were able to antagonize the positive modulatory effect of ligands chemically related to rimonabant [13]. Further studies afforded the identification of a number of selective/high affinity $\alpha+/ \beta-$ site ligands [14,15]. In fact, as suggested in the paper of Varagic et al. [14], the GABA receptor allosteric modulation by interaction with the new $\alpha+/ \beta-$ site, as exerted by analogues of CGS 9895 , is not dependent on the $\mathrm{GABA}_{\mathrm{A}}$ benzodiazepine-binding site $(\alpha+/ \beta-)$. In fact, the authors demonstrated that subtype receptors $\alpha 6 \beta 3$ and $\alpha 6 \beta 3 \gamma 2$ containing the same alpha subunit were modulated by some pyrazoloquinolines and pyrazolopyrimidinones, which did not interact with the 'benzodiazepine site', since the interface $\alpha+\beta$ - containing the $\alpha 6$ forms the well-known 'diazepam-insensitive' receptors. Even Knutson et al. [15] reported the study of new $\alpha 6 \beta 3$ not cytotoxic ligands as potential candidates for the treatment of CNS disorder and useful tools for drug development.

The achievement of the first crystal structure of the $\beta 3$ homopentamer human $\mathrm{GABA}_{\mathrm{A}}$ receptor at $3 \AA$ resolution [16] strongly improved the knowledge of the structural features of $G A B A_{A} R$. These results were recently corroborated by Zhu et al. [17], who obtained two high-resolution structures of $\mathrm{GABA}_{\mathrm{A}}$ receptor, in complex with GABA and flumazenil, using the cryo-electron microscopy. This study also revealed the presence of two sites located at equivalent positions to the GABA and benzodiazepine sites at the $\gamma / \beta$ and $\alpha / \beta$ interfaces (this last one has already been identified and is known as the $\alpha+/ \beta-$ 'non-traditional benzodiazepine' site) as potential targets for new drugs.

Our research group in a previous work reported the design and synthesis of new 8-methoxypyrazolo[1,5-a]quinazoline (PQ) and their 4,5-dihydro derivatives $(4,5(H) \mathrm{PQ})$ bearing the 
(hetero)arylalkylester (3-Het/ $\mathrm{ArCH}_{2} \mathrm{COO}-$ ) group at position 3. These ligands showed high binding affinity $\left(\mathrm{K}_{\mathrm{i}}=0.2-34 \mathrm{nM}\right)$ and anxiolityc-like/antihyperalgesic activity [18]. Continuing the study on ligands at the $\mathrm{GABA}_{\mathrm{A}}$ subtype receptor, we considered the shortening or the removal of the linker between the 3-(hetero)aryl ring and the PQ core as an interesting chemical modification of the previously reported ester derivatives. Thus, the synthesis of 8-methoxy 3-(hetero)arylpyrazolo[1,5-a]quinazoline and 3-(hetero)aroylpyrazolo[1,5-a]quinazoline was planned. These compounds are most likely more metabolically stable then ester derivatives [18], and are structurally strictly related to compounds that have been claimed to be GABA $A$ subtype receptor ligands such as Indiplon, Ocinaplon $[4,19,20]$, and compounds of type I and II [21-23] (Figure 1, Panel A). All of these compounds belong to the pyrazolopyrimidines, triazolophtalazine, or pyrazolobenzotriazine family, whose core is easily recovered in our new synthesized PQ compounds (Figure 1, Panel B).

(A)

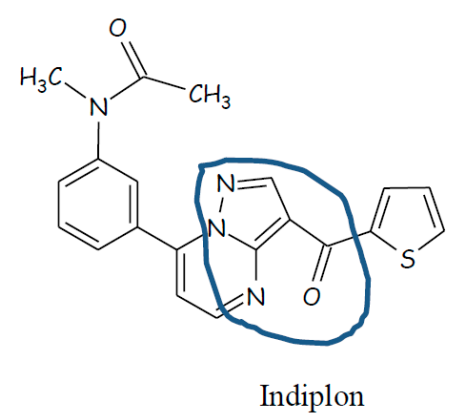

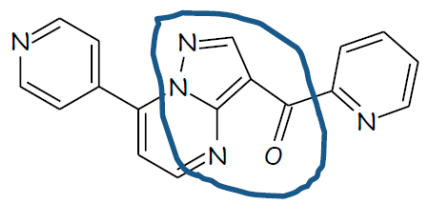

Indiplon

Ocinaplon
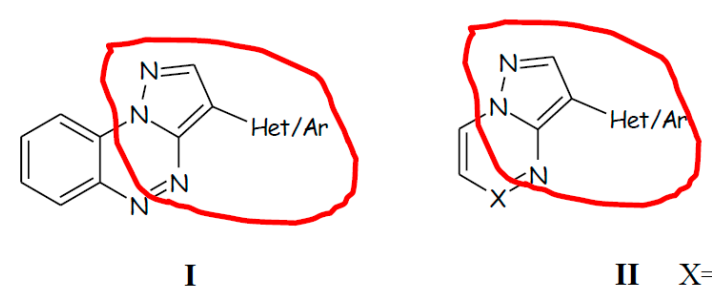

II $\mathrm{X}=\mathrm{CH}, \mathrm{N}$

(B)
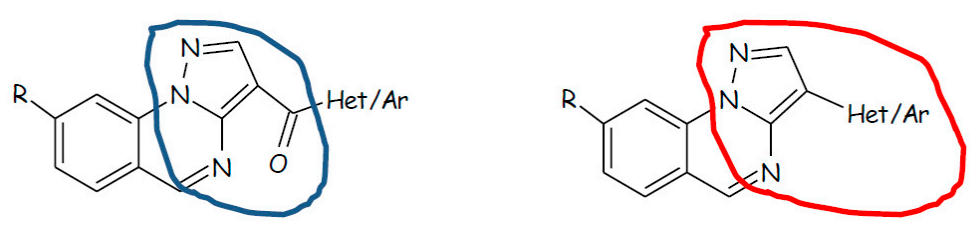

Figure 1. Panel (A): $\gamma$-aminobutyric type $A\left(G_{A B A}\right)$ receptor subtype ligands with chemical structures strictly related to the new pyrazoloquinazoline (PQ). Panel (B): general structure of new synthesized PQ compounds. Blue circle 3-aroylpyrazolopyrimidine moiety; Red circle 3-arylpyrazolopyrimidina moiety.

All new compounds were evaluated for their ability to displace [3H]flumazenil(Ro-151788) from its specific binding to $\mathrm{Bz}$ receptors in bovine membrane samples. Moreover, chlorine current on recombinant $\mathrm{GABA}_{\mathrm{A}}$ receptors of the $\alpha 1 \beta 2 \gamma 2 \mathrm{~L}$ type (expressed in frog oocytes of the Xenopus laevis species) was limited to those compounds that are able to inhibit radioligand binding by more than $80 \%$ at $10 \mu \mathrm{M}$. Additionally, for the most interesting compounds, the modulation on the new $\alpha+/ \beta-$ 'non-traditional' benzodiazepine site was evaluated.

\section{Results and Discussion}

\subsection{Chemistry}

Two synthetic approach were developed to obtain the desired 3-(hetero)arylpyrazolo[1,5-a] quinazolines or 3-(hetero)aroylpyrazolo[1,5-a]quinazolines: 
1- condensation and next cyclization of the hydrazinobenzoic acid with suitable propanenitrile to directly obtain the pyrazolo[1,5-a]quinazoline scaffold bearing at position 3 the proper (hetero)aryl or (hetero)aroyl group (Scheme 1);

2- introduction of the (hetero)aryl or (hetero)aroyl group through a functionalization of the position 3 (e.g., $-\mathrm{H},-\mathrm{COOH}$ ) working on the tricyclic system that was previously synthesized (Schemes 2 and 3$)$.

In the first approach (Scheme 1), the 2-hydrazinobenzoic acid or the 4-methoxy-2hydrazinobenzoic acid $\mathbf{1}$ and 2, [18] were reacted in $\mathrm{AcOH}$ or $\mathrm{DMF} / \mathrm{AcONa}$, with the appropriate 2-(hetero)aryl-3-oxapropanenitrile [21] or the corresponding 2-(hetero)aroyl-3-(dimethylamino) acrylonitrile [24], to obtain the final 3-(hetero)aryl (3a [25], 3b-e) and 3(heteroaroyl)pyrazolo [1,5-a]quinazolin-4(5H)-ones (3f-h), respectively.

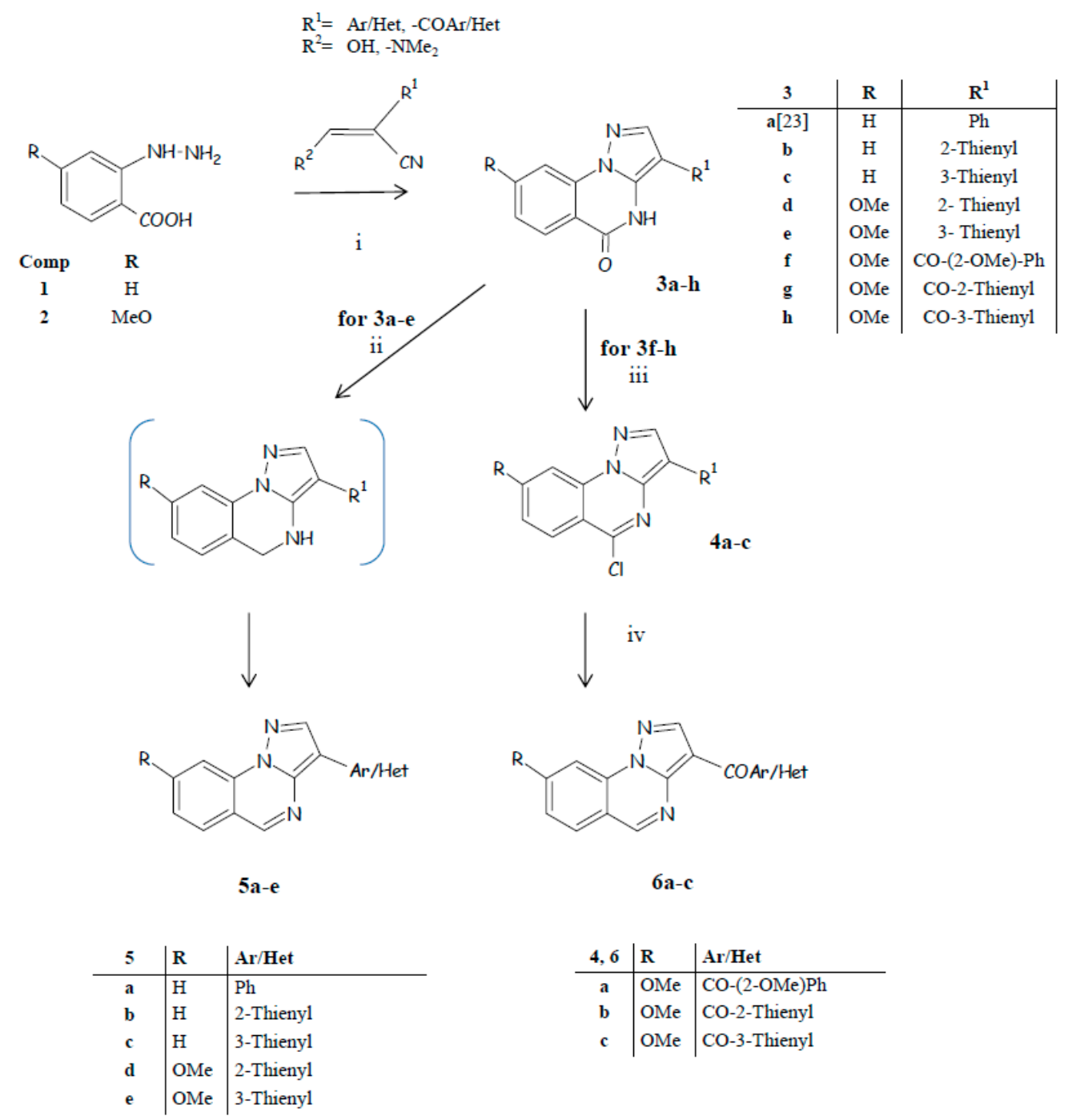

Scheme 1. Synthesis of pyrazolo[1,5-a]quinazolin-4(5H)-ones and pyrazolo[1,5-a]quinazolines bearing an aryl/heteroaryl ring or aroyl/heteroaroyl group at position 3. Reagents and conditions: (i) $\mathrm{AcOH}$ or dimethylformamide (DMF)/AcONa; (ii) anhydrous THF and $\mathrm{LiAlH}_{4} / \mathrm{THF}$ then air; (iii) $\mathrm{POCl}_{3} / \mathrm{PCl}_{5}, \mathrm{~N}, \mathrm{~N}$-diisopropylethylamine (DIPEA); (iv) $\mathrm{EtOH}, \mathrm{HCOONH}_{4}, \mathrm{Pd} / \mathrm{C} 10 \%$.

The aromatization of the quinazoline ring was obtained for compounds $3 \mathbf{a}-\mathbf{e}$ by treatment with $\mathrm{LiAlH}_{4}$ in anhydrous THF, and further oxidation in the same vessel reaction (the corresponding 4,5-dihydropyrazolo[1,5-a]quinazolines were not isolated) to directly give the aromatic compounds 
5a-e. Instead, compounds $\mathbf{3 f - h}$ were transformed into the corresponding 5-chloroderivatives (type 4 compounds), and the next reduction with $\mathrm{HCOONH}_{4}$ and $10 \% \mathrm{Pd} / \mathrm{C}$ yielded the final desired compounds $\mathbf{6 a}-\mathbf{c}$, without showing the corresponding dihydroderivatives.

In the second approach, modifications of position 3 of the pyrazolo[1,5-a]quinazoline scaffold were performed, depending on the final designed product (Schemes 2 and 3). For the introduction of the (hetero)aryl ring, the Suzuki coupling reaction was carried out (Scheme 2). The key intermediate 8 was obtained from 7 , the 8-methoxypyrazolo[1,5-a]quinazolin-5 $(4 \mathrm{H})$-one, by treatment with $\mathrm{LiAlH}_{4} / \mathrm{THF}$, and the next dehydrogenation with $10 \% \mathrm{Pd} / \mathrm{C}$ and toluene; compound 7 , in turn, was achieved by decarboxylation of ethyl 8-methoxy-5-oxo-4,5-dihydropyrazolo[1,5-a] quinazoline 3-carboxylate [18]. Halogenation of position 3 of the PQ core, by bromine or $\mathrm{N}$-iodosuccinimide (NIS), gave $\mathbf{9 a}, \mathbf{b}$, which were used as counterparts with the suitable boronic acid (2-MeO-phenyl-, 3-furan-, and 1-Boc-2-pyrrolboronic acid) in the Suzuki coupling reaction, yielding compounds $\mathbf{5} \mathbf{f}-\mathbf{h}$. The best yields were obtained starting from compound $\mathbf{9 b}$. The deprotection of 3-(1-Boc-2-pyrrolyl)-8-methoxypyrazolo[1,5-a]quinazoline, $5 \mathbf{h}$, by THF/MeONa, gave compound $5 \mathbf{i}$.<smiles>COc1ccc2c(=O)[nH]c3ccnn3c2c1</smiles><smiles>COc1ccc2cnc3ccnn3c2c1</smiles>

8

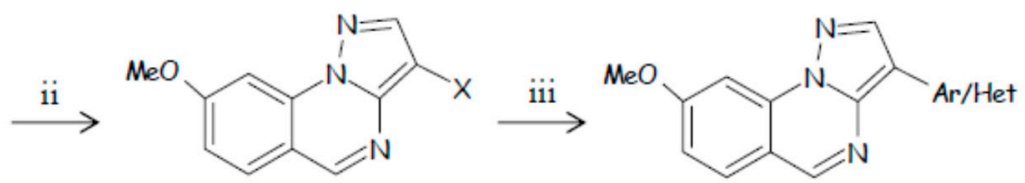

$9 \mathrm{a}, \mathrm{b}$

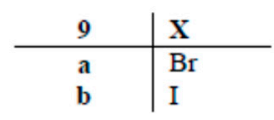

5f-i

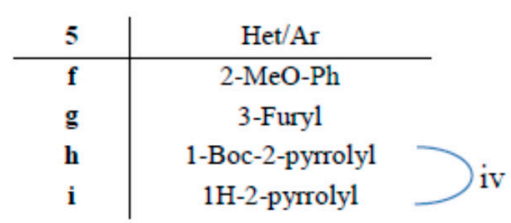

Scheme 2. Synthesis of 3-(hetero)arylpyrazolo[1,5-a]quinazoline. Reagents and conditions: (i) anhydrous THF and $\mathrm{LiAlH}_{4} / \mathrm{THF}$; then, toluene, $10 \% \mathrm{Pd} / \mathrm{C}$. (ii) $\mathrm{Br}_{2}$ or $\mathrm{NIS}, \mathrm{CH}_{2} \mathrm{Cl}_{2}$; (iii) Suzuki conditions, arylboronic acids, ethanol abs., $\left(\mathrm{PPh}_{3}\right)_{4} \mathrm{Pd}$ tetrakis(triphenylphosphine)palladium (0), sodium carbonate $2 \mathrm{M}$; (iv) THF/MeONa.

For the introduction of a keto group at position 3, still working on the tricyclic system, the 8-methoxypyazolo[1,5-a]quinazoline-3-carboxylic acid 10 [18] was used as the starting material. The 3-(4-methoxyphenylcarbonyl)-8-methoxypyrazolo[1,5-a]quinazoline $6 \mathbf{d}$ was obtained with Eaton's reagent and anisole, while the other compounds were obtained through the 3-acylchloride intermediate. The attempt to obtain the 3-carbonylderivatives by Suzuki coupling reaction failed, since for example, when using 2-MeO-phenylboronic acid as the counterpart, unexpectedly, only compound $\mathbf{5 f}$ was recovered, evidencing CO elimination and Ar-Ar coupling (Scheme 3). Thus, the Friedel-Craft reaction was applied and, after treatment of the 8-methoxypyazolo[1,5-a]quinazoline-3-carboxylic acid 9 with $\mathrm{SOCl}_{2}$ or $\mathrm{Cl}_{3} \mathrm{CCN}$ and $\mathrm{PPh}_{3}$ to give the 3 -acylchloride intermediate, the appropriate (hetero)aryl was added, and the final products $\mathbf{6 e}-\mathbf{g}$ were obtained. Compound $\mathbf{6 g}$ was also obtained by alkylation of $6 \mathbf{f}$ with $\mathrm{DMF}, \mathrm{K}_{2} \mathrm{CO}_{3}$, and methyl iodide, but in low yield. 


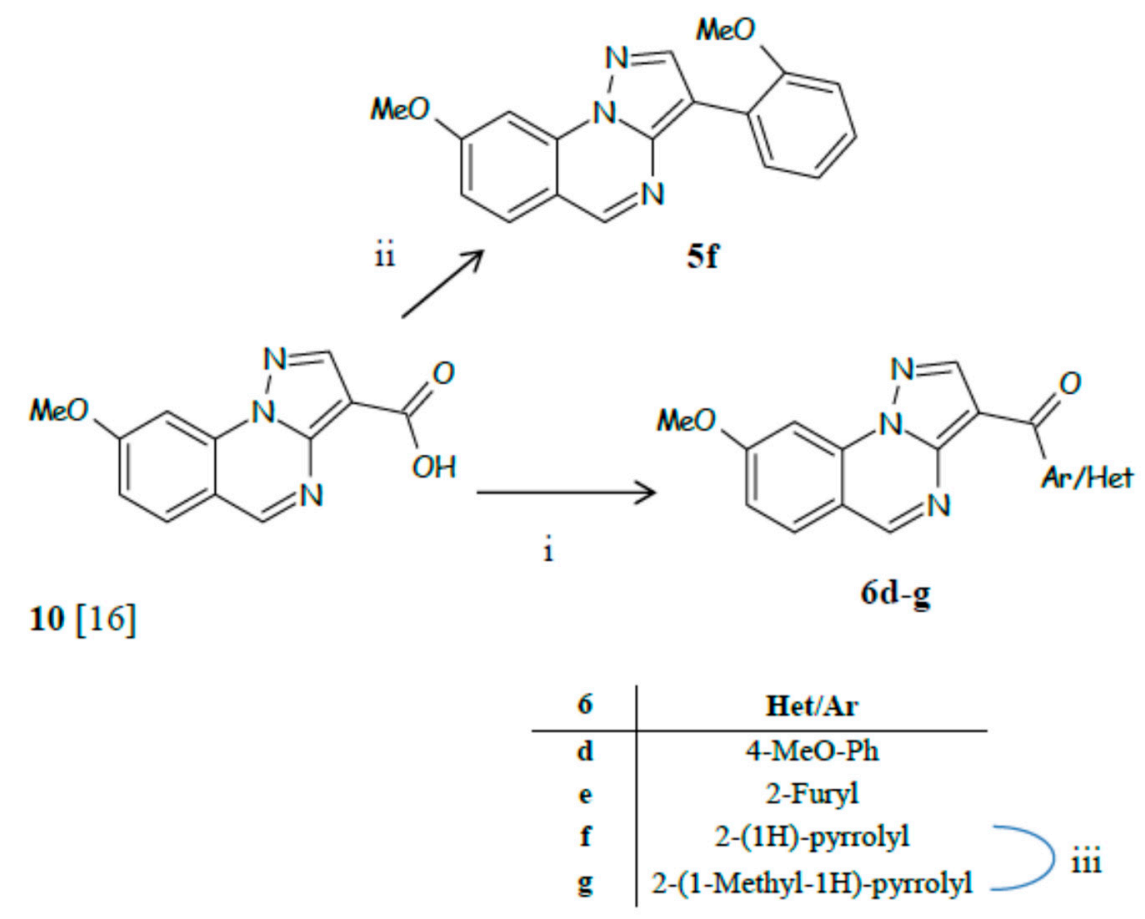

Scheme 3. Synthesis of 3-(hetero)aroylpyrazolo[1,5-a]quinazoline derivatives. Reagents and conditions: (i) For compound 6d Eaton's reagent and anisole; for $6 \mathbf{e}-\mathrm{g}$ : $\mathrm{SOCl}_{2}$ or $\mathrm{Cl}_{3} \mathrm{CCN} / \mathrm{PPh}_{3}$, then $\mathrm{SnCl}_{4}$ and suitable $\mathrm{ArH} / \mathrm{HetH}$; (ii) $\mathrm{SOCl}_{2}$, 2-MeO-PhB $(\mathrm{OH})_{2}$, toluene, $\mathrm{Na}_{2} \mathrm{CO}_{3}$ sol. $2 \mathrm{M}$; (iii) $\mathrm{DMF}, \mathrm{K}_{2} \mathrm{CO}_{3}$, MeI.

Finally, type 6 compounds were transformed into the corresponding 4,5-dihydroderivatives by treatment with $\mathrm{NaBH}_{3} \mathrm{CN}$ in $\mathrm{AcOH}$, obtaining compounds 11a, $\mathbf{b}$, and $\mathbf{d}-\mathbf{g}$, as shown in Scheme 4 . When 3-(hetero)aryl substituted compounds (type 5) were reacted in the same conditions, the corresponding 4,5-dihydroderivatives were evidenced only in the reaction mixture by TLC, and were not isolated as pure compounds, because after the normal work up, they were converted again into the starting material.<smiles>CCCCC(=O)c1cnn2c1NCc1ccc(OC)cc1-2</smiles>

6a, b, d-g

11a, b, d-g

\begin{tabular}{c|l}
$\mathbf{6 , 1 1}$ & Het/Ar \\
\hline $\mathbf{a}$ & $2-\mathrm{MeO}-\mathrm{Ph}$ \\
$\mathbf{b}$ & $2-\mathrm{Thienyl}$ \\
$\mathbf{d}$ & $4-\mathrm{MeO}-\mathrm{Ph}$ \\
$\mathbf{e}$ & $2-\mathrm{Furyl}$ \\
$\mathbf{f}$ & $2-(1 \mathrm{H})-$ pyrrolyl \\
$\mathbf{g}$ & $2-(1-\mathrm{Methyl}-1 \mathrm{H})-$ pyrrolyl
\end{tabular}

Scheme 4. Synthesis of 3-(hetero)aroyl-4,5-dihydropyrazolo[1,5-a]quinazolines. Reagents and conditions: (i) $\mathrm{AcOH} / \mathrm{NaBH}_{3} \mathrm{CN}$. 


\subsection{Biological Evaluation}

All of the new compounds were previously evaluated for their ability to displace $\left[{ }^{3} \mathrm{H}\right]$ flumazenil (Ro-151788) from its specific binding to Bz receptors in bovine membrane samples. Only compounds that were able to inhibit radioligand binding by more than $80 \%$ at $10 \mu \mathrm{M}(\mathbf{5 d}-\mathbf{f}, \mathbf{6 a}-\mathbf{d}, \mathbf{6} \mathbf{6}, \mathbf{g}, \mathbf{1 1 a}, \mathbf{b}, \mathbf{d})$ were further selected for electrophysiological studies on recombinant $\alpha 1 \beta 2 \gamma 2 \mathrm{~L} \mathrm{GABA}_{\mathrm{A}}$ receptors.

Recombinant $\alpha 1 \beta 2 \gamma 2 \mathrm{~L} \mathrm{GABA}_{\mathrm{A}}$ receptors were expressed in Xenopus laevis oocytes, and the effects of compounds tested at 1 to $100 \mu \mathrm{M}$ were assessed on the modulation of $\mathrm{GABA}_{\mathrm{A}}$ receptor function (Figure 2). The three sections of Figure 2 respectively report the experiments of pyrazoloquinazoline 3-(hetero)aryl substituted $\mathbf{5 d}-\mathbf{f}$ (section a), 3-(hetero)aroyl substituted 6a-d, 6f, $\mathbf{g}$ (section b), and 4,5-dihydropyrazoloquinazoline-3-(hetero)aroyl substituted 11a,b,d (section c).

(A)

$$
\alpha 1 \beta 2 \gamma 2 L
$$

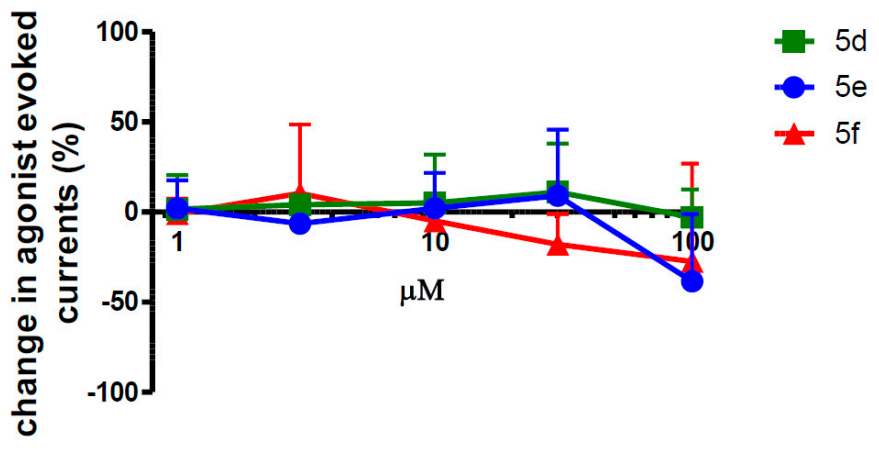

(B)

\section{$\alpha 1 \beta 2 \gamma 2 L$}

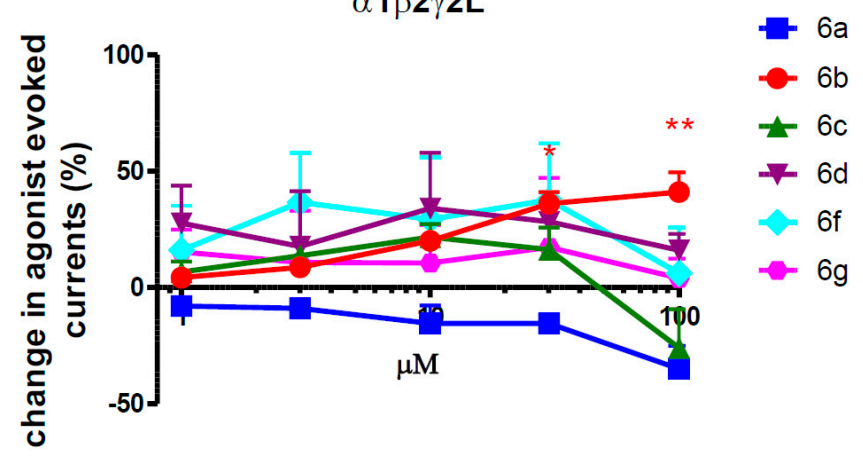

(C)

$\alpha 1 \beta 2 \gamma 2 L$

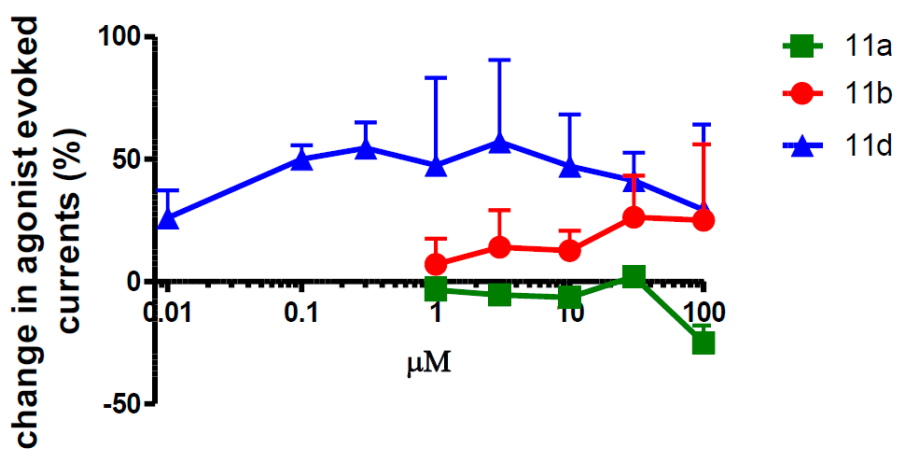

Figure 2. Concentration-response curves of compounds (A) $5 d-f,(B) 6 a-d, 6 f, g$, and (C) 11a,b,d on GABA-induced $\mathrm{Cl}^{-}$currents in Xenopus oocytes expressing recombinant $\alpha 1 \beta 2 \gamma 2 \mathrm{~L}$ GABA receptors. Data are expressed as the percentage modulation of the response induced by GABA at $\mathrm{EC}_{5-10}$ values, and are the mean \pm S.E.M of values obtained from two to nine oocytes. ${ }^{* *} p<0.01 ;{ }^{*} p<0.05$ Kruskal-Wallis test followed by the Dunn post-hoc test. 
As evident in Figure 2 (section A), the first group of compounds (5d-f) was not able to modulate the $\mathrm{GABA}_{\mathrm{A}}$ function through acting as a null modulator or antagonist. Among compounds 6a-d,f, $\mathbf{g}$ bearing an aroyl moiety at position 3 (Figure 2, section B), the 3-(2-methoxyphenylcarbonyl) -8-methoxypyrazolo[1,5-a]quinazoline 6a slightly, but not significantly, inhibited the GABA $\mathrm{A}_{\mathrm{A}}$ receptor function at $100 \mu \mathrm{M}$. On the contrary, the 3-(thien-2-yl-carbonyl)-8-methoxypyrazolo[1,5-a]quinazoline 6b, slightly but significantly enhanced the $\mathrm{GABA}_{\mathrm{A}}$ receptor function until $100 \mu \mathrm{M}$, showing an $\mathrm{EC}_{50}=11.97 \mu \mathrm{M}$ and acting as a partial agonist $\left(\mathrm{E}_{\max }+42 \%\right.$ at 100$)$

For the 4,5-dihydroderivatives 11a,b,d, which are reported in the third part of Figure 2 (section C), compound 11d stands out as enhancing the $\mathrm{GABA}_{\mathrm{A}}$ receptor function and reaching a maximum of activity at $1 \mu \mathrm{M}($ Emax $+54 \%)$, but maintaining a slightly positive variation in chloride current even at $\geq 0.01 \mu \mathrm{M}$.

In order to confirm whether those compounds that are null modulators act at the benzodiazepine binding site, $\mathbf{6} \mathbf{g}$ as a representative sample was evaluated for its ability to antagonize the full agonist diazepam. Figure 3 clearly demonstrated that the null modulator $6 \mathbf{g}$ is able to completely abolish the potentiation of the $\mathrm{GABA}_{\mathrm{A}}$ receptor function induced by $1 \mu$ diazepam at $10 \mu \mathrm{M}$.

$$
\alpha 1 \beta 2 \gamma 2 L
$$

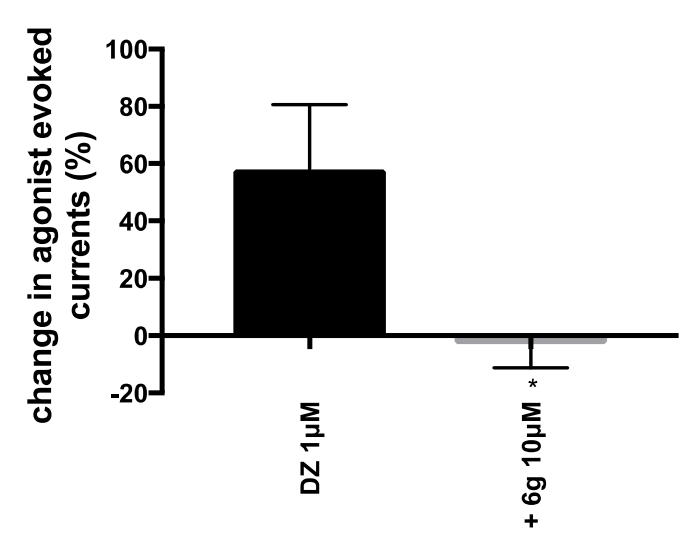

Figure 3. Compound $\mathbf{6 g}$ antagonized the potentiation of GABA-induced $\mathrm{Cl}^{-}$currents by diazepam in Xenopus oocytes expressing recombinant $\alpha 1 \beta 2 \gamma 2 \mathrm{~L} \mathrm{GABA}_{\mathrm{A}}$ receptors. Data are expressed as the percentage potentiation of the response induced by $\mathrm{GABA}_{\text {at }} \mathrm{EC}_{5-10}$ values, and are the mean $\pm \mathrm{SEM}$ of values obtained from four oocytes. $p<0.05$ Mann-Whitney test.

Recently, other low-affinity sites for benzodiazepine, in addition to the high-affinity benzodiazepine binding site, have been discovered $[9,17,26]$. Among them, the site located in the extracellular domain at the $\alpha+/ \beta$ - interface was demonstrated to be the target for the pyrazoloquinoline CGS 9895 (2-p-methoxyphenylpyrazolo[4,3-c]quinolin-3-(5H)-one, as shown in Figure 4), which was already identified as a null modulator (antagonist) at the high-affinity benzodiazepine site, and acts as a positive allosteric modulator [27]. Therefore, compound $6 \mathbf{g}$ was further tested for its ability to antagonize the potentiation of the GABA $\mathrm{A}_{\mathrm{A}}$ receptor induced by CGS 9895 . 

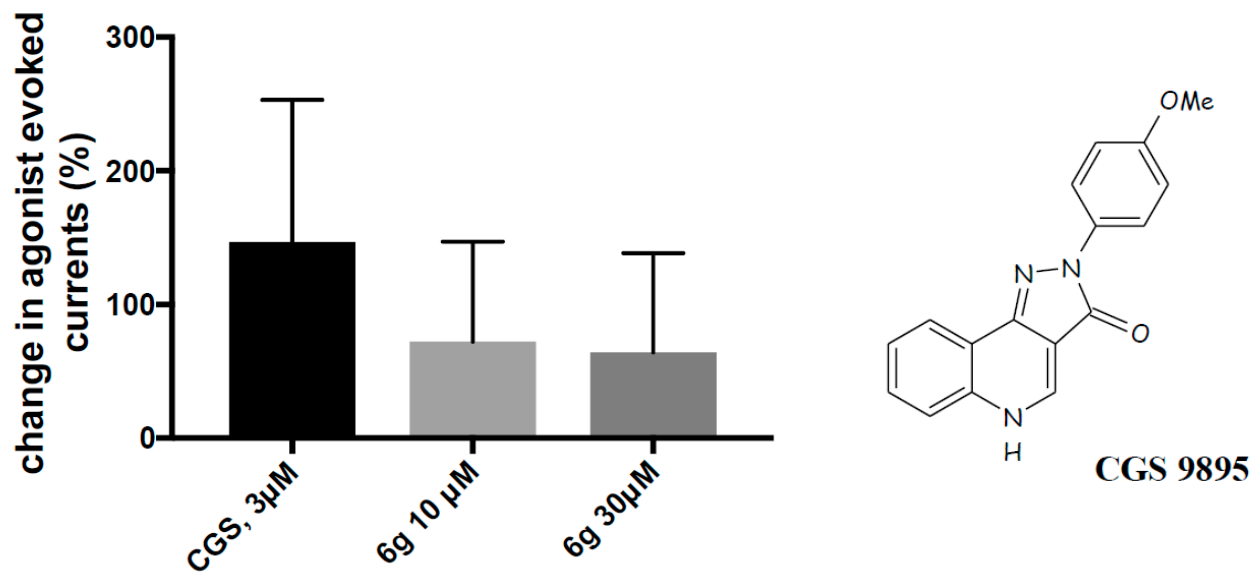

Figure 4. Compound $\mathbf{6 g}$ reduced the potentiation of GABA-induced $\mathrm{Cl}^{-}$currents by CGS 9895 (2-p-methoxyphenylpyrazolo[4,3-c]quinolin-3-(5H)-one) in Xenopus oocytes expressing recombinant $\alpha 1 \beta 2 \mathrm{GABA}_{\mathrm{A}}$ receptors. Data are expressed as the percentage potentiation of the response induced by GABA at $E_{5-10}$ values, and are the mean \pm SEM of values obtained from three to six oocytes.

The data obtained in $\mathrm{GABA}_{\mathrm{A}}$ receptors devoid of the $\gamma$ subunit $\left(\alpha_{1} \beta_{2}\right)$ indicates that compound $6 \mathrm{~g}$ reduces the potentiation of the GABA $\mathrm{A}_{\mathrm{A}}$ receptor induced by CGS $9895(10 \mu \mathrm{M})$ (about $-58 \%$ at both $10 \mu \mathrm{M}$ and $30 \mu \mathrm{M}$ ), suggesting that this compound binds the $\alpha+/ \beta-$ low-affinity site, too. This interesting result seems to suggest that our compounds acting as null modulators or antagonists could be selective $\alpha+/ \beta$ - low-affinity benzodiazepine binding site ligands. This hypothesis was preliminarily confirmed by compounds $\mathbf{5} \mathbf{d}$ and $\mathbf{5 e}$, which in the same test completely blocked or strongly reduced the potentiation of the $\mathrm{GABA}_{\mathrm{A}}$ receptor function induced by CGS 9895, respectively (data not shown). In accordance with Sieghart et al. (2012) [8], we believe that drugs acting at the "non-canonical" $\alpha+/ \beta-$ low-affinity binding site might display potential clinical relevance. It has been proposed that the compounds acting at this site could be beneficial for long-term epilepsy treatment. In fact, they will be able to interact with a broader variety of $\mathrm{GABA}_{\mathrm{A}}$ receptors a subtypes such as the $\delta, \varepsilon$, and $\pi$ subunit-containing $\mathrm{GABA}_{\mathrm{A}}$ receptors.

Results from electrophysiological studies on recombinant $\alpha 1 \beta 2 \gamma 2 \mathrm{~L} \mathrm{GABA}_{\mathrm{A}}$ receptors showed that the 3-aroyl derivatives are able to slightly induce a change in the agonist-evoked current. This evidence led us to speculate that the aroyl moiety at position 3 of the PQ scaffold could be responsible for this effect. The more active compounds $\mathbf{6 a}$ and $\mathbf{6} \mathbf{b}$ respectively bear the 2-methoxybenzoyl and thien-2-yl-carbonyl groups at position 3, which are both able to engage hydrogen bond interaction with receptor proteins. Also, it is noteworthy that compound $6 \mathrm{~b}$ retains the same pyrazolo[1,5-a]pyrimidine substructure as indiplon (Figure 1), which is already known as a partial agonist. In particular, the carbonyl moiety $(\mathrm{CO})$ and the 2-methoxy (2-OMe) substituent on the phenyl ring for $\mathbf{6 a}$ and the sulfur atom of the thienyl ring for $\mathbf{6 b}$ could provoke a change of conformation favorable for the effect; this is different from the 3-aryl substituted PQ, which is devoid of activity.

The very interesting result obtained with the 3-(4-methoxyphenylcarbonyl)-8-methoxy-4,5dihydropyrazolo[1,5-a]quinazoline 11d, that shows an enhanced current at $1 \mu \mathrm{M}$, encouraged us to synthesize other derivatives with the 4,5-dihydropyrazolo[1,5-a]quinazoline scaffold, which is certainly worthy of remark.

\section{Material and Methods}

Melting points were determined with a Gallenkamp apparatus and were uncorrected. Silica gel plates (Merk $\mathrm{F}_{254}$ ) and silica gel 60 (Merk 70-230 mesh) were used for analytical and column chromatography, respectively. The structures of all the compounds were supported by their IR spectra (KBr pellets in nujol mulls, Perkin-Elmer 1420 spectrophotometer) and ${ }^{1} \mathrm{H}-\mathrm{NMR}$ data (measured with a Bruker $400 \mathrm{MHz}$ ). Chemical shifts were expressed in $\delta \mathrm{ppm}$, using DMSO- $\mathrm{d}_{6}$ or $\mathrm{CDCl}_{3}$ as solvent. 
The chemical and physical data of new compounds are shown in Table S1; all of the microanalyses were performed with a Perkin-Elmer 260 analyzer for $\mathrm{C}, \mathrm{H}$, and N. Mass spectra $(\mathrm{m} / \mathrm{z})$ were recorded on an Electrospray ionisation time-of-flight mass spectrometry ESI-TOF mass spectrometer (Bruker Micro TOF), and reported mass values are within the error limits of $\pm 5 \mathrm{ppm}$ mass units. Microanalyses indicated by the symbols of the elements or functions were performed with a Perkin-Elmer 260 elemental analyzer for $\mathrm{C}, \mathrm{H}$, and $\mathrm{N}$, and they were within $\pm 0.4 \%$ of the theoretical values.

\subsection{General Procedure for the Synthesis of $\mathbf{3 b}-\mathbf{e}$}

A suspension of 2-hydrazinobenzoic acid (1) or 2-hydrazino-4-methoxybenzoic acid (2) (1.0 mmol) and 3-oxo-2-(2-thienyl)-propionitrile, 3-oxo-2-(3-thienyl)-propionitrile (1.1 mmol) in acetic acid (5 mL) was refluxed until the starting material disappeared in TLC (toluene/ethyl acetate/acetic acid 8:2:1 $v / v / v$ as eluent). The final solution was treated with ice/water, and the precipitate was filtered and purified by recrystallization by a suitable solvent.

\subsubsection{3-(Thien-2-yl)pyrazolo[1,5-a]quinazolin-5(4H)-one (3b)}

From 1 and 3-oxo-2-(2-thienyl)-propionitrile. Cream crystals, yield 80\%; IR $v \mathrm{~cm}^{-1} 3120,1674$; ${ }^{1} \mathrm{H}-\mathrm{NMR}$ (DMSO-d 6 ) $\delta 12.07$ (bs, $1 \mathrm{H}, \mathrm{NH}$, exch.); 8.14 (d, 1H, H-9, J = 8.0); 8.09 (d, 1H, H-6, J = 8.0); 7.99 (s, 1H, H-2); 7.89 (t, 1H, H-7, J = 7.8 Hz); 7.50 (t, 1H, H-8, J = 7.8 Hz); 7.46 (d, 1H, H-3 thienyl, $J=4.8 \mathrm{~Hz}) ; 7.38(\mathrm{~d}, 1 \mathrm{H}, \mathrm{H}-5$ thienyl, $J=3.6) ; 7.11\left(\mathrm{~m}, 1 \mathrm{H}, \mathrm{H}-4\right.$ thienyl). ESI-MS calcd for $\mathrm{C}_{14} \mathrm{H}_{9} \mathrm{~N}_{3} \mathrm{OS}$ (267.31); found: $m / z 268.01[\mathrm{M}+\mathrm{H}]^{+}$. Anal $\mathrm{C}_{14} \mathrm{H}_{9} \mathrm{~N}_{3} \mathrm{OS}(\mathrm{C}, \mathrm{H}, \mathrm{N})$.

\subsubsection{3-(Thien-3-yl)pyrazolo[1,5-a]quinazolin-5(4H)-one (3c)}

From 1 and 3-oxo-2-(3-thienyl)-propionitrile. Cream crystals, yield 52\%; IR v cm ${ }^{-1} 3120,1674$; ${ }^{1} \mathrm{H}-\mathrm{NMR}\left(\mathrm{CDCl}_{3}\right) \delta 9.22$ (bs, $1 \mathrm{H}, \mathrm{NH}$, exch.); 8.29 (d, $\left.1 \mathrm{H}, \mathrm{H}-9, J=8.0\right) ; 8.20$ (d, $\left.1 \mathrm{H}, \mathrm{H}-6, J=8.0\right) ; 7.88$ (s, 1H, H-2); $7.81(\mathrm{t}, 1 \mathrm{H}, \mathrm{H}-7, J=7.8 \mathrm{~Hz}) ; 7.48(\mathrm{~m}, 2 \mathrm{H}, \mathrm{H}-8$, and H-2 thienyl); 7.35 (m, 2H, H-4, and $\mathrm{H}-5$ thienyl). ESI-MS calcd for $\mathrm{C}_{14} \mathrm{H}_{9} \mathrm{~N}_{3} \mathrm{OS}$ (267.31); found: $m / z 267.88[\mathrm{M}+\mathrm{H}]^{+}$. Anal $\mathrm{C}_{14} \mathrm{H}_{9} \mathrm{~N}_{3} \mathrm{OS}$ $(\mathrm{C}, \mathrm{H}, \mathrm{N})$.

\subsubsection{8-Methoxy-3-(thien-2-yl)pyrazolo[1,5-a]quinazolin-5(4H)-one (3d)}

From 2 and 3-oxo-2-(2-thienyl)-propionitrile. Cream crystals, yield 90\%; IR v cm ${ }^{-1} 3137,1697$; ${ }^{1} \mathrm{H}-\mathrm{NMR}$ (DMSO-d 6 ) $\delta 11.89$ (bs, 1H, NH, exch.); 8.05 (d, 1H, H-6, J = 8.8 Hz); 7.98 (s, 1H, H-2); 7.51 $(\mathrm{d}, \mathrm{H}-9, J=2.0 \mathrm{~Hz}) ; 7.46$ (d, 1H, H-3 thienyl, $J=4.8 \mathrm{~Hz}) ; 7.38$ (d, 1H, H-5 thienyl, $J=3.4 \mathrm{HZ}) ; 7.09$ $(\mathrm{dd}, 1 \mathrm{H}, \mathrm{H}-4$ thienyl, $J=4.8 \mathrm{~Hz}, J=3.4 \mathrm{~Hz}) ; 7.06(\mathrm{dd}, 1 \mathrm{H}, \mathrm{H}-7, J=8.8 \mathrm{~Hz}, J=2.0 \mathrm{~Hz}) ; 3.94\left(\mathrm{~s}, 3 \mathrm{H}, \mathrm{OCH}_{3}\right)$. ESI-MS calcd for $\mathrm{C}_{15} \mathrm{H}_{11} \mathrm{~N}_{3} \mathrm{O}_{2} \mathrm{~S}$ (297.33); found: $m / z$ 297.93[M + H] $]^{+}$. Anal. $\mathrm{C}_{15} \mathrm{H}_{11} \mathrm{~N}_{3} \mathrm{O}_{2} \mathrm{~S}(\mathrm{C}, \mathrm{H}, \mathrm{N})$.

\subsubsection{8-Methoxy-3-(thien-3-yl)pyrazolo[1,5-a]quinazolin-5(4H)-one (3e)}

From 2 and 3-oxo-2-(3-thienyl)-propionitrile. Cream crystals, yield 67\%; IR v cm ${ }^{-1} 3110,1687$; ${ }^{1} \mathrm{H}-\mathrm{NMR}\left(\mathrm{DMSO}_{\mathrm{d}}\right.$ ) $\delta 11.78$ (bs, 1H, NH, exch.); 8.16 (s, 1H, H-2); 8.05 (d, 1H, H-6, J = 9.0 Hz); $7.84(\mathrm{~m}, 1 \mathrm{H}, \mathrm{H}-2$ thienyl); 7.59 (m, 1H, H-4 thienyl); 7.51 (d, H-9, J = 2.4 Hz); 7.49 (d, 1H, H-5 thienyl, $J=4.0 \mathrm{~Hz}) ; 7.05(\mathrm{dd}, 1 \mathrm{H}, \mathrm{H}-7, J=9.0 \mathrm{~Hz}, J=2.4 \mathrm{~Hz}) ; 3.94\left(\mathrm{~s}, 3 \mathrm{H}, \mathrm{OCH}_{3}\right)$. ESI-MS calcd for $\mathrm{C}_{15} \mathrm{H}_{11} \mathrm{~N}_{3} \mathrm{O}_{2} \mathrm{~S}$ (297.33); found: $m / z$ 298.03[M+ H] $]^{+}$. Anal. $\mathrm{C}_{15} \mathrm{H}_{11} \mathrm{~N}_{3} \mathrm{O}_{2} \mathrm{~S}(\mathrm{C}, \mathrm{H}, \mathrm{N})$.

\subsection{General Procedure for the Synthesis of $\mathbf{3} \mathbf{f}-\mathbf{h}$}

A suspension of 2-hydrazino-4-methoxybenzoic acid (2, $1.09 \mathrm{mmol}), 2$-aroyl-3-(dimethylamino) acrylonitrile $(1.09 \mathrm{mmol})$, and anhydrous sodium acetate $(1.31 \mathrm{mmol})$ in DMF $(4 \mathrm{~mL})$ was refluxed until the starting material disappeared in TLC (toluene/ethyl acetate/methanol 8:2:1.5 $v / v / v$ as eluent). The final solution was treated with ice/water, and the precipitate was filtered and purified by recrystallization by a suitable solvent. 


\subsubsection{8-Methoxy-3-(2-methoxybenzoyl)pyrazolo[1,5-a]quinazolin-5(4H)-one (3f)}

From 2 and 2-benzoyl-3-(dimethylamino)acrylonitrile. Cream crystals, yield 50\%; IR v cm${ }^{-1} 3167$, 1687, 1674; ${ }^{1} \mathrm{H}-\mathrm{NMR}$ (DMSO-d 6 ) $\delta 11.29$ (bs, 1H, NH, exch.); 8.09 (d, 1H, H-6, J = 8.8 Hz); 7.86 (s, $1 \mathrm{H}$, H-2); $7.52(\mathrm{t}, 1 \mathrm{H}, \mathrm{H}-4$ phenyl, $J=8.4 \mathrm{~Hz}) ; 7.49$ (d, H-9, $J=2.0 \mathrm{~Hz}) ; 7.38(\mathrm{~d}, 1 \mathrm{H}, \mathrm{H}-6$ phenyl, $J=6.4 \mathrm{~Hz})$; $7.19(\mathrm{~d}, 1 \mathrm{H}, \mathrm{H}-3$ phenyl, $J=8.4 \mathrm{~Hz}) ; 7.13(\mathrm{dd}, 1 \mathrm{H}, \mathrm{H}-7 \mathrm{~J}=8.8 \mathrm{~Hz}, J=2.0 \mathrm{~Hz}) ; 7.06(\mathrm{t}, 1 \mathrm{H}, \mathrm{H}-5$ phenyl, $J=7.2 \mathrm{~Hz}) ; 3.94\left(\mathrm{~s}, 3 \mathrm{H}, 8-\mathrm{OCH}_{3}\right) ; 3.77\left(\mathrm{~s}, 3 \mathrm{H}, \mathrm{OCH}_{3}\right)$. ESI-MS calcd for $\mathrm{C}_{19} \mathrm{H}_{15} \mathrm{~N}_{3} \mathrm{O}_{4}(349,34)$; found: $m / z$ 349.94[M + H] $]^{+}$. Anal. $\mathrm{C}_{19} \mathrm{H}_{15} \mathrm{~N}_{3} \mathrm{O}_{4}(\mathrm{C}, \mathrm{H}, \mathrm{N})$.

\subsubsection{8-Methoxy-3-(thien-2-ylcarbonyl)pyrazolo[1,5-a]quinazolin-5(4H)-one (3g)}

From 2 and 2-(2-thienylcarbonyl)-3-(dimethylamino)acrylonitrile. Pale yellow crystals, yield 65\%; IR $v \mathrm{~cm}^{-1} 3327,1699,1678 ;{ }^{1} \mathrm{H}-\mathrm{NMR}$ (DMSO-d 6 ) $\delta 11.23$ (bs, 1H, NH, exch.); 8.62 (s, 1H, H-2); 8.13-8.05 (m, 3H, H-6 and H-3, H-5 thienyl); $7.53(\mathrm{~d}, 1 \mathrm{H}, \mathrm{H}-9 \mathrm{~J}=2.0 \mathrm{~Hz}) ; 7.30(\mathrm{~m}, 1 \mathrm{H}, \mathrm{H}-4$ thienyl); $3.95(\mathrm{~s}, 3 \mathrm{H}$, $\mathrm{OCH}_{3}$ ). ESI-MS calcd for $\mathrm{C}_{16} \mathrm{H}_{11} \mathrm{~N}_{3} \mathrm{O}_{3} \mathrm{~S}(325,34)$; found: $m / z 326.04[\mathrm{M}+\mathrm{H}]^{+}$. Anal. $\mathrm{C}_{16} \mathrm{H}_{11} \mathrm{~N}_{3} \mathrm{O}_{3} \mathrm{~S}$ $(\mathrm{C}, \mathrm{H}, \mathrm{N})$.

\subsubsection{8-Methoxy-3-(thien-3-ylcarbonyl)pyrazolo[1,5-a]quinazolin-5(4H)-one (3h)}

From 2 and 2-(3-thienylcarbonyl)-3-(dimethylamino)acrylonitrile. Pale yellow crystals, yield 65\%; IR v cm ${ }^{-1} 3310,1698,1678 ;{ }^{1} \mathrm{H}-\mathrm{NMR}\left(\mathrm{DMSO}_{-} \mathrm{d}_{6}\right) \delta 11.24$ (bs, $1 \mathrm{H}, \mathrm{NH}$, exch.); 8.54 (d, $1 \mathrm{H}, \mathrm{H}-2$ thienyl, $J=1.2 \mathrm{~Hz}) ; 8.48(\mathrm{~s}, 1 \mathrm{H}, \mathrm{H}-2) ; 8.10(\mathrm{~d}, 1 \mathrm{H}, \mathrm{H}-6, J=8.8 \mathrm{~Hz}) ; 7.71(\mathrm{dd}, 1 \mathrm{H}, \mathrm{H}-5$ thienyl, $J=5.2 \mathrm{~Hz}$, $J=2.8 \mathrm{~Hz}) ; 7.59(\mathrm{~d}, 1 \mathrm{H}, \mathrm{H}-4$ thienyl, $J=4.8 \mathrm{~Hz}) ; 7.54(\mathrm{~d}, \mathrm{H}-9, J=2.0 \mathrm{~Hz}) ; 7.15(\mathrm{dd}, 1 \mathrm{H}, \mathrm{H}-7, J=8.8 \mathrm{~Hz}$, $J=2.0 \mathrm{~Hz}) ; 3.96\left(\mathrm{~s}, 3 \mathrm{H}, \mathrm{OCH}_{3}\right)$. ESI-MS calcd for $\mathrm{C}_{16} \mathrm{H}_{11} \mathrm{~N}_{3} \mathrm{O}_{3} \mathrm{~S}(325,34)$; found: $m / z 325.94[\mathrm{M}+\mathrm{H}]^{+}$. Anal. $\mathrm{C}_{16} \mathrm{H}_{11} \mathrm{~N}_{3} \mathrm{O}_{3} \mathrm{~S}(\mathrm{C}, \mathrm{H}, \mathrm{N})$.

\subsection{General Procedure for the Synthesis of $\mathbf{4 a - c}$}

A solution of $\mathbf{3 f}-\mathbf{h}(0.3 \mathrm{mmol})$ in $\mathrm{POCl}_{3}(3 \mathrm{~mL})$ was heated $\left(40-80{ }^{\circ} \mathrm{C}\right)$ and maintained under stirring until the starting material disappeared, as evaluated by TLC (toluene/ethyl acetate/methanol 8:2:1.5 $v / v / v$ as eluent). The final solution was evaporated, and the residue was recuperated with ice/water, filtered, and washed with water and ethanol $80 \%$.

\subsubsection{3-(2-Methoxyphenylcarbonyl)-5-chloro-8-methoxypyrazolo[1,5-a]quinazoline (4a)}

Pale cream crystals, yield 95\%; IR $v \mathrm{~cm}^{-1} 1674 ;{ }^{1} \mathrm{H}-\mathrm{NMR}\left(\right.$ DMSO-d $\left._{6}\right) \delta 8.44(\mathrm{~s}, 1 \mathrm{H}, \mathrm{H}-2) ; 8.19(\mathrm{~d}, 1 \mathrm{H}$, $\mathrm{H}-6, J=9.2 \mathrm{~Hz}) ; 7.80(\mathrm{~d}, \mathrm{H}-9, J=2.0 \mathrm{~Hz}) ; 7.52(\mathrm{t}, 1 \mathrm{H}, \mathrm{H}-4$ phenyl, $J=8.4 \mathrm{~Hz}) ; 7.36(\mathrm{~d}, 2 \mathrm{H}, \mathrm{H}-6$ phenyl and $\mathrm{H}-3$ phenyl, $J=6.8 \mathrm{~Hz}) ; 7.15(\mathrm{~d}, 1 \mathrm{H}, \mathrm{H}-7 \mathrm{~J}=8.4 \mathrm{~Hz}) ; 7.04(\mathrm{t}, 1 \mathrm{H}, \mathrm{H}-5$ phenyl, $J=7.2 \mathrm{~Hz}) ; 4.04(\mathrm{~s}, 3 \mathrm{H}$, 8- $\left.\mathrm{OCH}_{3}\right) ; 3.64\left(\mathrm{~s}, 3 \mathrm{H}, \mathrm{OCH}_{3}\right)$. ESI-MS calcd for $\mathrm{C}_{19} \mathrm{H}_{14} \mathrm{~N}_{3} \mathrm{O}_{3} \mathrm{Cl}(367,79)$; found: $m / z 368.39[\mathrm{M}+\mathrm{H}]^{+}$. Anal. $\mathrm{C}_{19} \mathrm{H}_{14} \mathrm{~N}_{3} \mathrm{O}_{3} \mathrm{Cl}(\mathrm{C}, \mathrm{H}, \mathrm{N})$.

\subsubsection{3-(Thien-2-ylcarbonyl)-5-chloro-8-methoxypyrazolo[1,5-a]quinazoline (4b)}

Pale yellow crystals, yield 95\%; IR $v \mathrm{~cm}^{-1} 1648 ;{ }^{1} \mathrm{H}-\mathrm{NMR}\left(\mathrm{DMSO}^{-\mathrm{d}_{6}}\right) \delta 8.72(\mathrm{~s}, 1 \mathrm{H}, \mathrm{H}-2) ; 8.22$ $(\mathrm{d}, 1 \mathrm{H}, \mathrm{H}-6, J=9.2 \mathrm{~Hz}) ; 8.13(\mathrm{~d}, 1 \mathrm{H}, \mathrm{H}-3$ thienyl $J=2.8 \mathrm{~Hz}) ; 8.06(\mathrm{~d}, 1 \mathrm{H}, \mathrm{H}-5$ thienyl, $J=4.4 \mathrm{~Hz}) ; 7.82$ $(\mathrm{d}, 1 \mathrm{H}, \mathrm{H}-9 \mathrm{~J}=2.0 \mathrm{~Hz}) ; 7.36(\mathrm{dd}, 1 \mathrm{H}, \mathrm{H}-7, J=8.8 \mathrm{~Hz}, J=2.0 \mathrm{~Hz}) ; 7.29(\mathrm{~m}, 1 \mathrm{H}, \mathrm{H}-4$ thienyl); $4.05(\mathrm{~s}, 3 \mathrm{H}$, $\mathrm{OCH}_{3}$ ). ESI-MS calcd for $\mathrm{C}_{16} \mathrm{H}_{10} \mathrm{~N}_{3} \mathrm{O}_{2} \mathrm{SCl}(343,79)$; found: $m / z 344.49[\mathrm{M}+\mathrm{H}]^{+}$. Anal. $\mathrm{C}_{16} \mathrm{H}_{10} \mathrm{~N}_{3} \mathrm{O}_{2} \mathrm{SCl}$ $(\mathrm{C}, \mathrm{H}, \mathrm{N})$.

\subsubsection{3-(Thien-3-ylcarbonyl)-5-chloro-8-methoxypyrazolo[1,5-a]quinazoline (4c)}

Pale yellow crystals, yield 75\%; IR $v \mathrm{~cm}^{-1} 1647 ;{ }^{1} \mathrm{H}-\mathrm{NMR}\left(\mathrm{DMSO}^{\left.-\mathrm{d}_{6}\right)} \delta 8.66\right.$ (s, 1H, H-2); 8.48 $(\mathrm{d}, 1 \mathrm{H}, \mathrm{H}-2$ thienyl, $J=1.2 \mathrm{~Hz}) ; 8.23(\mathrm{~d}, 1 \mathrm{H}, \mathrm{H}-6, J=8.8 \mathrm{~Hz}) ; 7.85(\mathrm{~d}, \mathrm{H}-9, J=2.0 \mathrm{~Hz}) ; 7.66(\mathrm{~m}, 1 \mathrm{H}, \mathrm{H}-5$ thienyl); $7.59(\mathrm{~d}, 1 \mathrm{H}, \mathrm{H}-4$ thienyl, $J=4.8 \mathrm{~Hz}) ; 7.38(\mathrm{dd}, 1 \mathrm{H}, \mathrm{H}-7, J=8.8 \mathrm{~Hz}, J=2.0 \mathrm{~Hz}) ; 4.06(\mathrm{~s}, 3 \mathrm{H}$, $\mathrm{OCH}_{3}$ ). ESI-MS calcd for $\mathrm{C}_{16} \mathrm{H}_{10} \mathrm{~N}_{3} \mathrm{O}_{2} \mathrm{SCl}(343,79)$; found: $m / z 344.49[\mathrm{M}+\mathrm{H}]^{+}$. Anal. $\mathrm{C}_{16} \mathrm{H}_{10} \mathrm{~N}_{3} \mathrm{O}_{2} \mathrm{SCl}$ $(\mathrm{C}, \mathrm{H}, \mathrm{N})$. 


\subsection{General Procedure for the Synthesis of 5a-e}

$\mathrm{LiAlH}_{4} / \mathrm{THF}$ solution $(2.8 \mathrm{mmol})$ was added to a suspension of $3 \mathbf{a}$ [25] and $3 \mathbf{b}-\mathbf{e}(1.0 \mathrm{mmol})$ in anhydrous THF and the mixture refluxed. The reaction was monitored with TLC (toluene/ethyl acetate/methanol 8:2:1.5 $v / v / v$ as eluent) until the starting material disappeared and a mixture of compounds was formed: the 4,5-dihydro and the 4,5-dehydro derivatives. Thus, the reaction was maintained at air to permit the complete oxidation to final pyrazolo[1,5-a]quinazoline derivatives. The careful addition of water, the next extraction with ethyl acetate, and the followed evaporation gave the final desired compounds.

\subsubsection{3-Phenylpyrazolo[1,5-a]quinazoline (5a)}

Yellow crystals, yield 75\%; ${ }^{1} \mathrm{H}-\mathrm{NMR}\left(\mathrm{DMSO}_{\mathrm{d}}\right) \delta 9.24(\mathrm{~s}, 1 \mathrm{H}, \mathrm{H}-5) ; 8.84(\mathrm{~d}, 1 \mathrm{H}, \mathrm{H}-9, J=8.0 \mathrm{~Hz}$ ); $8.67(\mathrm{~s}, 1 \mathrm{H}, \mathrm{H}-2) ; 8.29$ (d, 2H, H-2 phenyl and H-6 phenyl, $J=8.0 \mathrm{~Hz}) ; 8.24-8.19(\mathrm{~m}, 2 \mathrm{H}, \mathrm{H}-6$, and H-4 phenyl); $7.86(\mathrm{t}, 1 \mathrm{H}, \mathrm{H}-8, J=8.0 \mathrm{~Hz}) ; 7.73(\mathrm{t}, 2 \mathrm{H}, \mathrm{H}-3$ phenyl and $\mathrm{H}-5$ phenyl, $J=8.0 \mathrm{~Hz}) ; 7.56(\mathrm{t}, 1 \mathrm{H}$, $\mathrm{H}-7, J=8.0 \mathrm{~Hz}$ ). ${ }^{13} \mathrm{C}-\mathrm{NMR}\left(\mathrm{DMSO}_{-} \mathrm{d}_{6}\right) \delta 155.7,131.9,130.8,129.1,128.7,127.5,97.5$. ESI-MS calcd for $\mathrm{C}_{16} \mathrm{H}_{11} \mathrm{~N}_{3}(245,10)$; found: $m / z 245.8[\mathrm{M}+\mathrm{H}]^{+}$. Anal. $\mathrm{C}_{16} \mathrm{H}_{11} \mathrm{~N}_{3}(\mathrm{C}, \mathrm{H}, \mathrm{N})$.

\subsubsection{3-(Thien-2-yl)pyrazolo[1,5-a]quinazoline (5b)}

Pale yellow crystals, yield 52\%; ${ }^{1} \mathrm{H}-\mathrm{NMR}\left(\mathrm{DMSO}_{\mathrm{d}} \mathrm{)}\right) \delta 9.08$ (s, 1H, H-5); 8.62 (s, 1H, H-2); 8.37 (d, 1H, H-9, J = 8.0); 8.21 (d, 1H, H-6, J = 8.0); 7.82-7.63 (m, 2H, H-8, and H-5 thienyl); $7.46(\mathrm{~d}, 1 \mathrm{H}, \mathrm{H}-3$ thienyl $J=4.6 \mathrm{~Hz}) ; 7.25(\mathrm{t}, 1 \mathrm{H}, \mathrm{H}-7, J=8.8 \mathrm{~Hz}) ; 7.27(\mathrm{dd}, 1 \mathrm{H}, \mathrm{H}-4$ thienyl, $J=4.6 \mathrm{~Hz}, J=3.8) .{ }^{13} \mathrm{C}-\mathrm{NMR}$ (DMSO-d6) $\delta 165.5,154.9,145.7,137.7,135.4$ 135.1, 135.0, 131.8, 129.1, 120.8, 97.5. ESI-MS calcd for $\mathrm{C}_{15} \mathrm{H}_{11} \mathrm{~N}_{3} \mathrm{OS}(281,33)$; found: $\mathrm{m} / \mathrm{z} 281.93[\mathrm{M}+\mathrm{H}]+$. Anal. $\mathrm{C}_{15} \mathrm{H}_{11} \mathrm{~N}_{3} \mathrm{OS}(\mathrm{C}, \mathrm{H}, \mathrm{N})$.

\subsubsection{3-(Thien-3-yl)pyrazolo[1,5-a]quinazoline (5c)}

Yellow crystals, yield 47\%; ${ }^{1} \mathrm{H}-\mathrm{NMR}\left(\mathrm{DMSO}_{\mathrm{d}}\right) \delta 9.16$ (s, 1H, H-5); 8.64 (s, 1H, H-2); 8.37 (d, $1 \mathrm{H}$, $\mathrm{H}-9, J=8.0) ; 8.21$ (d, $1 \mathrm{H}, \mathrm{H}-6, J=8.0) ; 8.04-7.99(\mathrm{~m}, 2 \mathrm{H}, \mathrm{H}-8$, and $\mathrm{H}-2$ thienyl); $7.84(\mathrm{~d}, 1 \mathrm{H}, \mathrm{H}-5$ thienyl, $J=4.8 \mathrm{~Hz}$ ); 7.67 (m, 2H, H-7, and H-4 thienyl). ${ }^{13} \mathrm{C}-\mathrm{NMR}\left(\mathrm{DMSO}^{-} \mathrm{d}_{6}\right) \delta 155.7,133.4,132.3,128.3,127.7$, 127.4, 124.7, 76.8. ESI-MS calcd for $\mathrm{C}_{14} \mathrm{H}_{9} \mathrm{~N}_{3} \mathrm{~S}(251,31)$; found: $m / z 252.71[\mathrm{M}+\mathrm{H}]^{+}$. Anal. $\mathrm{C}_{14} \mathrm{H}_{9} \mathrm{~N}_{3} \mathrm{~S}$ $(\mathrm{C}, \mathrm{H}, \mathrm{N})$.

\subsubsection{3-(Thien-2-yl)-8-methoxypyrazolo[1,5-a]quinazoline (5d)}

Pale yellow crystals, yield 75\%; ${ }^{1} \mathrm{H}-\mathrm{NMR}\left(\mathrm{DMSO}_{6}\right) \delta 9.05$ (s, 1H, H-5); 8.59 (s, 1H, H-2); 8.14 $(\mathrm{d}, 1 \mathrm{H}, \mathrm{H}-6 \mathrm{~J}=8.8 \mathrm{~Hz}) ; 7.75(\mathrm{~d}, 1 \mathrm{H}, \mathrm{H}-9 \mathrm{~J}=2.0 \mathrm{~Hz}) ; 7.63(\mathrm{~d}, 1 \mathrm{H}, \mathrm{H}-5$ thienyl, $J=3.8 \mathrm{~Hz}) ; 7.46(\mathrm{~d}, 1 \mathrm{H}$, H-3 thienyl $J=4.6 \mathrm{~Hz}) ; 7.25(\mathrm{dd}, 1 \mathrm{H}, \mathrm{H}-7, J=8.8 \mathrm{~Hz}, J=2.0 \mathrm{~Hz}) ; 7.27(\mathrm{dd}, 1 \mathrm{H}, \mathrm{H}-4$ thienyl, $J=4.6 \mathrm{~Hz}$, $J=3.8) ; 4.01\left(\mathrm{~s}, 3 \mathrm{H}, \mathrm{OCH}_{3}\right) .{ }^{13} \mathrm{C}-\mathrm{NMR}\left(\mathrm{DMSO}_{-} \mathrm{d}_{6}\right) \delta 165.5,154.9,145.7,137.7,135.4$ 135.1, 135.0, 131.8, 129.1, 120.8, 117.5, 106.4, 55.8. ESI-MS calcd for $\mathrm{C}_{15} \mathrm{H}_{11} \mathrm{~N}_{3} \mathrm{OS}(281,33)$; found: $m / z 281.93[\mathrm{M}+\mathrm{H}]^{+}$. Anal. $\mathrm{C}_{15} \mathrm{H}_{11} \mathrm{~N}_{3} \mathrm{OS}(\mathrm{C}, \mathrm{H}, \mathrm{N})$.

\subsubsection{3-(Thien-3-yl)-8-methoxypyrazolo[1,5-a]quinazoline (5e)}

Pale yellow crystals, yield 70\%; ${ }^{1} \mathrm{H}-\mathrm{NMR}\left(\mathrm{DMSO}_{6}\right) \delta 9.04(\mathrm{~s}, 1 \mathrm{H}, \mathrm{H}-5) ; 8.62$ (s, 1H, H-2); 8.13 $(\mathrm{d}, 1 \mathrm{H}, \mathrm{H}-6, J=8.8 \mathrm{~Hz}) ; 8.03(\mathrm{~d}, 1 \mathrm{H}, \mathrm{H}-2$ thienyl $J=2.8 \mathrm{~Hz}) ; 7.85(\mathrm{dd}, 1 \mathrm{H}, \mathrm{H}-4$ thienyl, $J=5.0 \mathrm{~Hz}$, $J=1.2 \mathrm{~Hz}) ; 7.75(\mathrm{~d}, \mathrm{H}-9, J=2.2 \mathrm{~Hz}) ; 7.63(\mathrm{dd}, 1 \mathrm{H}, \mathrm{H}-5$ thienyl $J=5.0 \mathrm{~Hz}, J=3.0 \mathrm{~Hz}) ; 7.24(\mathrm{dd}, 1 \mathrm{H}, \mathrm{H}-7$, $J=8.8 \mathrm{~Hz}, J=2.2 \mathrm{~Hz}) ; 4.01\left(\mathrm{~s}, 3 \mathrm{H}, \mathrm{OCH}_{3}\right) .{ }^{13} \mathrm{C}-\mathrm{NMR}\left(\mathrm{DMSO}_{\mathrm{d}}\right) \delta 165.9,155.4,145.5,136.7,128.9,127.6$, $125.2,120.8,117.5,106.4,55.8$. ESI-MS calcd for $\mathrm{C}_{15} \mathrm{H}_{11} \mathrm{~N}_{3} \mathrm{OS}(281,33)$; found: $m / z 281.93[\mathrm{M}+\mathrm{H}]^{+}$. Anal. $\mathrm{C}_{15} \mathrm{H}_{11} \mathrm{~N}_{3} \mathrm{OS}(\mathrm{C}, \mathrm{H}, \mathrm{N})$.

\subsection{General Procedure for the Synthesis of $\mathbf{5} \mathbf{f}-\mathbf{h}$}

Triphenylphosphine palladium (0) (Tetrakis, $0.035 \mathrm{mmol}$ ), $2.4 \mathrm{~mL}$ of $\mathrm{Na}_{2} \mathrm{CO}_{3}$ solution $2 \mathrm{M}$, and suitable (hetero)arylboronic acid $(0.60 \mathrm{mmol})$ solubilized in $1 \mathrm{~mL}$ of absolute ethanol were added 
to a solution of 3-iodo- or 3-bromo-8-methoxypyrazolo[1,5-a]quinazoline ( $9 \mathbf{a}, \mathbf{9} \mathbf{b}$, see below) $(0.2 \mathrm{mmol})$ in anhydrous THF $(6 \mathrm{~mL})$. The suspension was refluxed until the starting material disappeared in TLC; then, it was diluted with ethyl acetate, and water was added. The organic layer was separated and dried over $\mathrm{Na}_{2} \mathrm{SO}_{4}$ anhydrous and evaporated to dryness. The final compounds were purified by recrystallization by a suitable solvent. In general, it has been observed that from starting material $\mathbf{9 a}$, the yield of coupling is better than starting from $\mathbf{9 b}$.

\subsubsection{3-(2-Methoxyphenyl)-8-methoxypyrazolo[1,5-a]quinazoline (5f)}

From 9a and 2-methoxyphenylboronic acid. Cream crystals, yield $45 \%$ (from $\mathbf{9 b}$ yield $20 \%$ ); TLC:cyclohexane/ethyl acetate 2:1 v/v; ${ }^{1} \mathrm{H}-\mathrm{NMR}\left(\mathrm{CDCl}_{3}\right) \delta 8.82(\mathrm{~s}, 1 \mathrm{H}, \mathrm{H}-5) ; 8.61$ (s, $\left.1 \mathrm{H}, \mathrm{H}-2\right) ; 8.20$ $(\mathrm{dd}, 1 \mathrm{H}, \mathrm{H}-7, J=8.2 \mathrm{~Hz}, J=2.0 \mathrm{~Hz}) ; 7.87(\mathrm{~d}, \mathrm{H}-9, J=2.0 \mathrm{~Hz}) ; 7.83(\mathrm{~d}, 1 \mathrm{H}, \mathrm{H}-6, J=8.2 \mathrm{~Hz}) ; 7.30(\mathrm{dt}, 1 \mathrm{H}$, H-4 phenyl, $J=8.4 \mathrm{~Hz}, J=1.6 \mathrm{~Hz}$ ); 7.13-7.08 (m, 2H, H-5, H-6 phenyl); 7.03 (d, 1H, H-3 phenyl, $J=8.4 \mathrm{~Hz}) ; 4.05\left(\mathrm{~s}, 3 \mathrm{H}, 8-\mathrm{OCH}_{3}\right) ; 3.92\left(\mathrm{~s}, 3 \mathrm{H}, \mathrm{OCH}_{3}\right) .{ }^{13} \mathrm{C}-\mathrm{NMR}\left(\mathrm{DMSO}-\mathrm{d}_{6}\right) \delta 165.3,160.9,155.0,145.6$, 145.2, 137.7, 133.6, 131.7, 126.6, 123.9, 123.7, 117.5, 114.4, 113.8, 104.6, 96.3, 56.8, 55.8. ESI-MS calcd for $\mathrm{C}_{18} \mathrm{H}_{15} \mathrm{~N}_{3} \mathrm{O}_{2}$ (305,33); found: $m / z$ 305.93[M + H] $]^{+}$. Anal. $\mathrm{C}_{18} \mathrm{H}_{15} \mathrm{~N}_{3} \mathrm{O}_{2}(\mathrm{C}, \mathrm{H}, \mathrm{N})$.

This compound was the only one product recovered by treatment of 10 with $\mathrm{SOCl}_{2}$ and 2-MeO-PhB(OH $)_{2}$ in toluene and $\mathrm{Na}_{2} \mathrm{CO}_{3}$ sol. $2 \mathrm{M}$, in the attempt to obtain the 3-(2-methoxyphenylcarbonyl)-8-methoxypyrazolo[1,5-a]quinazoline 6a, yield $15 \%$.

\subsubsection{3-(Fur-3-yl)-8-methoxypyrazolo[1,5-a]quinazoline (5g)}

From 9a and 3-furylboronic acid. Pale yellow crystals, yield $43 \%$ (from $9 \mathbf{b}$ yield $22 \%$ ); TLC: CHX/ethyl acetate 4:1 v/v; ${ }^{1} \mathrm{H}-\mathrm{NMR}\left(\mathrm{DMSO}_{\mathrm{d}}\right) \delta 8.97(\mathrm{~s}, 1 \mathrm{H}, \mathrm{H}-5) ; 8.47(\mathrm{~s}, 1 \mathrm{H}, \mathrm{H}-2) ; 8.13(\mathrm{~m}, 2 \mathrm{H}$, H-6 and H-4 furyl); 7.27 (m, 2H, H-2 furyl and H-9); 7.21 (dd, $1 \mathrm{H}, \mathrm{H}-7, J=8.8 \mathrm{~Hz}, J=2.2 \mathrm{~Hz}$ ); 7.10 (s, 1H, H-5 furyl); 3.98 (s, 3H, OCH ${ }_{3}$ ). ${ }^{13} \mathrm{C}-\mathrm{NMR}\left(\mathrm{DMSO}_{\mathrm{d}}\right.$ ) $\delta$ 155.4, 144.1, 138.5, 133.4, 128.9, 120.8, $108.8,106.4,76.8$, 55.8. ESI-MS calcd for $\mathrm{C}_{15} \mathrm{H}_{11} \mathrm{~N}_{3} \mathrm{O}_{2}(265,27)$; found: $m / z$ 265.97[M + H] $]^{+}$. Anal. $\mathrm{C}_{15} \mathrm{H}_{11} \mathrm{~N}_{3} \mathrm{O}_{2}(\mathrm{C}, \mathrm{H}, \mathrm{N})$.

\subsubsection{Tert-Butyl 2-(8-methoxypyrazolo[1,5-a]quinazolin-3-yl)-1H-pyrrole-1-carboxylate (5h)}

From 9a and N-BOC-pyrrol-2-boronic acid. Oil, yield 37\%; (from 9b yield 18\%); TLC: toluene/ethyl acetate/acetic acid 8:2:1 v/v/v; ${ }^{1} \mathrm{H}-\mathrm{NMR}\left(\mathrm{CDCl}_{3}\right) \delta 8.77(\mathrm{~s}, 1 \mathrm{H}, \mathrm{H}-5) ; 8.18(\mathrm{~s}, 1 \mathrm{H}$, $\mathrm{H}-2) ; 8.13(\mathrm{~m}, 2 \mathrm{H}, \mathrm{H}-6$, and H-9); 7.41 (dd, $1 \mathrm{H}, \mathrm{H}-3$ pyrrole, $J=3.2 \mathrm{~Hz}, J=1.6 \mathrm{~Hz}) ; 7.10(\mathrm{dd}, 1 \mathrm{H}, \mathrm{H}-7$, $J=8.8 \mathrm{~Hz}, J=2.4 \mathrm{~Hz}) ; 6.46(\mathrm{~d}, 1 \mathrm{H}, \mathrm{H}-5$ pyrrole, $J=2.8 \mathrm{~Hz}) ; 4.02\left(\mathrm{~s}, 3 \mathrm{H}, \mathrm{OCH}_{3}\right) ; 1.35(\mathrm{~s}, 9 \mathrm{H}, \mathrm{t}-\mathrm{Bu})$. ${ }^{13}$ C-NMR $\left(\right.$ DMSO-d $_{6}$ ) $\delta 155.4,150.2,133.4,128.9,120.8,119.2,115.9,106.4,99.0,84.2,55.8,28.4$. ESI-MS calcd for $\mathrm{C}_{20} \mathrm{H}_{20} \mathrm{~N}_{4} \mathrm{O}_{3}$ (364.40); found: $m / z$ 365.0[M + H] $]^{+}$. Anal. $\mathrm{C}_{20} \mathrm{H}_{20} \mathrm{~N}_{4} \mathrm{O}_{3}(\mathrm{C}, \mathrm{H}, \mathrm{N})$.

\subsection{3-(1H-Pyrrol-2-yl)-8-methoxypyrazolo[1,5-a]quinazoline (5i)}

A solution of $5 \mathbf{h}(0.11 \mathrm{mmol})$ in $2 \mathrm{~mL}$ of anhydrous THF was added to $1.5 \mathrm{~mL}$ of sodium methoxide solution $0.43 \mathrm{M}$. The reaction was kept at $40{ }^{\circ} \mathrm{C}$ for $4 \mathrm{~h}$; then, it was cooled and diluted with ice/water until a precipitate was formed. Then, it was filtered and recrystallized by ethanol; yield 69\%. TLC:CHX/ethyl acetate 4:1 v/v; ${ }^{1} \mathrm{H}-\mathrm{NMR}\left(\mathrm{CDCl}_{3}\right) \delta 10.32$ (bs, $1 \mathrm{H}, \mathrm{NH}$, exch.); 8.73 (s, $\left.1 \mathrm{H}, \mathrm{H}-5\right)$; $8.30(\mathrm{~s}, 1 \mathrm{H}, \mathrm{H}-2) ; 7.84(\mathrm{~m}, 2 \mathrm{H}, \mathrm{H}-6$ and H-9); $7.11(\mathrm{dd}, 1 \mathrm{H}, \mathrm{H}-7, J=8.8 \mathrm{~Hz}, J=2.0 \mathrm{~Hz}) ; 6.93(\mathrm{~m}, 1 \mathrm{H}, \mathrm{H}-3$ pyrrole); 6.54 (m, 1H, H-5 pyrrole); 6.30 (m. 1H, H-4 pyrrole); $4.05\left(\mathrm{~s}, 3 \mathrm{H}, \mathrm{OCH}_{3}\right) .{ }^{13} \mathrm{C}-\mathrm{NMR}\left(\mathrm{CDCl}_{3}\right)$ $\delta 165.8,155.4,146.8,133.4,120.8,120.2,124.0,111.5,106.8,106.4,55.8$. ESI-MS calcd for $\mathrm{C}_{15} \mathrm{H}_{12} \mathrm{~N}_{4} \mathrm{O}$ (264.28); found: $m / z 264.88[\mathrm{M}+\mathrm{H}]^{+}$. Anal. $\mathrm{C}_{15} \mathrm{H}_{12} \mathrm{~N}_{4} \mathrm{O}(\mathrm{C}, \mathrm{H}, \mathrm{N})$.

\subsection{General Procedure for the Synthesis of $\mathbf{6 a - c}$}

Ammonium formate $97 \%$ ( $7.83 \mathrm{mmol})$ and $20 \mathrm{mg}$ of the catalyst $\mathrm{Pd} / \mathrm{C} 10 \%$ was added to a solution of $4 \mathbf{a}-\mathbf{c}(0.3 \mathrm{mmol})$ in ethanol abs. $(4 \mathrm{~mL})$. The reaction was maintained at reflux temperature for $1 \mathrm{~h}$; 
then, the filtration of the catalyst and the next evaporation of the solution gave a residue that was recovered by ethanol $80 \%$.

\subsubsection{3-(2-Methoxyphenylcarbonyl)-8-methoxypyrazolo[1,5-a]quinazoline (6a)}

Pale cream crystals, yield 68\%; IR $v \mathrm{~cm}^{-1} 1639 ;{ }^{1} \mathrm{H}-\mathrm{NMR}\left(\mathrm{DMSO}^{-\mathrm{d}_{6}}\right) \delta 9.11$ (s, 1H, H-5); 8.45 (s, 1H, H-2); 8.18 (d, 1H, H-6, J = 8.8 Hz); 7.79 (d, H-9, J = 2.0 Hz); 7.50 (t, 1H, H-4 phenyl, $J=8.4 \mathrm{~Hz})$; 7.36-7.31 (m, 2H, H-7, and H-6 phenyl); $7.13(\mathrm{~d}, 1 \mathrm{H}, \mathrm{H}-3$ phenyl, $J=8.4 \mathrm{~Hz}) ; 7.03(\mathrm{t}, 1 \mathrm{H}, \mathrm{H}-5$ phenyl, $J=7.6 \mathrm{~Hz}) ; 4.03\left(\mathrm{~s}, 3 \mathrm{H}, 8-\mathrm{OCH}_{3}\right) ; 3.61\left(\mathrm{~s}, 3 \mathrm{H}, \mathrm{OCH}_{3}\right) .{ }^{13} \mathrm{C}-\mathrm{NMR}\left(\mathrm{DMSO}_{\mathrm{d}} \mathrm{d}_{6}\right) \delta 196.3,165.3,160.9,155.0$, $145.6,145.2,137.7,133.6,131.7,126.6,123.9,123.7,117.5,114.4,113.8,104.6,96.3,56.8,55.8$. ESI-MS calcd for $\mathrm{C}_{19} \mathrm{H}_{15} \mathrm{~N}_{3} \mathrm{O}_{3}(333,34)$; found: $m / z$ 333.94[M + H] $]^{+}$. Anal. $\mathrm{C}_{19} \mathrm{H}_{15} \mathrm{~N}_{3} \mathrm{O}_{3}(\mathrm{C}, \mathrm{H}, \mathrm{N})$.

\subsubsection{3-(Thien-2-ylcarbonyl)-8-methoxypyrazolo[1,5-a]quinazoline (6b)}

Pale yellow crystals, yield 74\%; IR cm ${ }^{-1} 1640 ;{ }^{1} \mathrm{H}-\mathrm{NMR}\left(\right.$ DMSO-d $\left._{6}\right) \delta 9.22$ (s, 1H, H-5); 8.70 (s, 1H, H-2); 8.21 (m, 2H, H-6 and H-3 thienyl); 8.03 (d, 1H, H-5 thienyl, $J=4.8 \mathrm{~Hz}) ; 7.82(\mathrm{~d}, 1 \mathrm{H}, \mathrm{H}-9$, $J=2.0 \mathrm{~Hz}) ; 7.34(\mathrm{dd}, 1 \mathrm{H}, \mathrm{H}-7, J=8.8 \mathrm{~Hz}, J=2.0 \mathrm{~Hz}) ; 7.27(\mathrm{dd}, 1 \mathrm{H}, \mathrm{H}-4$ thienyl, $J=4.4 \mathrm{~Hz}, J=4.0) ; 4.03$ $\left(\mathrm{s}, 3 \mathrm{H}, \mathrm{OCH}_{3}\right) .{ }^{13} \mathrm{C}-\mathrm{NMR}\left(\mathrm{DMSO}-\mathrm{d}_{6}\right) \delta 179.5,165.5,154.9,145.7,137.7,135.4$ 135.1, 135.0, 131.8, 129.1, $120.8,117.5,106.4$, 55.8. ESI-MS calcd for $\mathrm{C}_{16} \mathrm{H}_{11} \mathrm{~N}_{3} \mathrm{O}_{2} \mathrm{~S}(309,34)$; found: $m / z 309.94[\mathrm{M}+\mathrm{H}]^{+}$. Anal. $\mathrm{C}_{16} \mathrm{H}_{11} \mathrm{~N}_{3} \mathrm{O}_{2} \mathrm{~S}(\mathrm{C}, \mathrm{H}, \mathrm{N})$.

\subsubsection{3-(Thien-3-ylcarbonyl)-8-methoxypyrazolo[1,5-a]quinazoline (6c)}

Pale yellow crystals, yield 70\%; IR $v \mathrm{~cm}^{-1} 1640 ;{ }^{1} \mathrm{H}-\mathrm{NMR}\left(\mathrm{DMSO}^{-\mathrm{d}_{6}}\right) \delta 9.22(\mathrm{~s}, 1 \mathrm{H}, \mathrm{H}-5) ; 8.70$ (s, 1H, H-2); 8.49 (s, 1H, H-2 thienyl); 8.20 (d, 1H, H-6, J = $8.8 \mathrm{~Hz}) ; 7.82(\mathrm{~d}, \mathrm{H}-9, J=2.0 \mathrm{~Hz}) ; 7.66$ (m, 1H, H-5 thienyl); 7.59 (d, 1H, H-4 thienyl, $J=4.8 \mathrm{~Hz}) ; 7.34$ (dd, 1H, H-7, J = 8.8 Hz, J = 2.0 Hz); 4.04 $\left(\mathrm{s}, 3 \mathrm{H}, \mathrm{OCH}_{3}\right) .{ }^{13} \mathrm{C}-\mathrm{NMR}\left(\mathrm{DMSO}-\mathrm{d}_{6}\right) \delta 192.1,165.9,155.4,145.5,136.7,128.9,127.6,125.2,120.8,117.5$, 106.4, 55.8. ESI-MS calcd for $\mathrm{C}_{16} \mathrm{H}_{11} \mathrm{~N}_{3} \mathrm{O}_{2} \mathrm{~S}(309,34)$; found: $m / z$ 309.94[M+ H] $]^{+}$. Anal. $\mathrm{C}_{16} \mathrm{H}_{11} \mathrm{~N}_{3} \mathrm{O}_{2} \mathrm{~S}$ $(\mathrm{C}, \mathrm{H}, \mathrm{N})$.

\subsection{3-(4-Methoxyphenylcarbonyl)-8-methoxypyrazolo[1,5-a]quinazoline (6d)}

A 100-mL round-bottomed flask was charged with 8-methoxypyrazolo[1,5-a] quinazoline-3carboxylic acid, 10 [18] $(0.3 \mathrm{mmol})$, and the commercially available Eaton's reagent $(7.7 \%, w / w$, of $\mathrm{P}_{2} \mathrm{O}_{5}$ in $\mathrm{MsOH}$ ) (2.5 equiv) was added. The solution was kept at $60{ }^{\circ} \mathrm{C}$ for $20 \mathrm{~min}$. After that, anisole $(0.35 \mathrm{mmol})$ was added and maintained for $2 \mathrm{~h}$ at $60^{\circ} \mathrm{C}$. The final solution was treated with saturated solution of $\mathrm{NaHCO}_{3}$ to reach $\mathrm{pH} 8$; the obtained precipitate was filtered and purified by recrystallization. Pale cream crystals, yield $66 \%$; IR $v \mathrm{~cm}^{-1} 1639 ;{ }^{1} \mathrm{H}-\mathrm{NMR}\left(\mathrm{DMSO}-\mathrm{d}_{6}\right) \delta 9.13(\mathrm{~s}, 1 \mathrm{H}$, $\mathrm{H}-5) ; 8.56$ (s, 1H, H-2); 8.20 (d, 1H, H-6, J = $8.8 \mathrm{~Hz}) ; 7.88$ (d, 2H, H-2 and H-6 phenyl, $J=8.0 \mathrm{~Hz}$ ); 7.82 $(\mathrm{d}, 1 \mathrm{H}, \mathrm{H}-9, J=2.0 \mathrm{~Hz}) ; 7.33(\mathrm{dd}, 1 \mathrm{H}, \mathrm{H}-7, J=8.0 \mathrm{~Hz}, J=2.2 \mathrm{~Hz}) ; 7.04(\mathrm{~d}, 2 \mathrm{H}, \mathrm{H}-3$ and H-5 phenyl, $J=8.0 \mathrm{~Hz}) ; 4.03\left(\mathrm{~s}, 3 \mathrm{H}, 8-\mathrm{OCH}_{3}\right) ; 3.84\left(\mathrm{~s}, 3 \mathrm{H}, \mathrm{OCH}_{3}\right) .{ }^{13} \mathrm{C}-\mathrm{NMR}\left(\mathrm{DMSO}-\mathrm{d}_{6}\right) \delta 187.1,165.3,163.2,154.6$, 154.5, 145.9, 144.6, 137.7, 132.3, 131.7, 131.6, 129.2, 120.7, 117.5, 117.2, 114.0, 113.8, 113.6, 112.9, 112.2, 96.4, 56.8, 55.9. ESI-MS calcd for $\mathrm{C}_{19} \mathrm{H}_{15} \mathrm{~N}_{3} \mathrm{O}_{3}(333,34)$; found: $m / z 333.94[\mathrm{M}+\mathrm{H}]^{+}$. Anal. $\mathrm{C}_{19} \mathrm{H}_{15} \mathrm{~N}_{3} \mathrm{O}_{3}$ (C, H, N).

\subsection{General Procedure for The Synthesis of $\mathbf{6 e -} \mathbf{- g}$}

The starting material 8-methoxypyrazolo[1,5-a]quinazoline-3-carboxylic acid, 10 [18] (0.3 mmol), was suspended in $\mathrm{CH}_{2} \mathrm{Cl}_{2}, 0.15 \mathrm{~mL}$ of trichloroacetonitrile, and $1.45 \mathrm{mmol}$ of $\mathrm{PPh}_{3}$. The mixture was maintained at room temperature for $2 \mathrm{~h}$, monitoring the reaction by TLC; when the corresponding 3-carbonylchloride was formed, $\mathrm{SnCl}_{4}$ anhydrous $(0.9 \mathrm{~mL})$ and the suitable heteroaryl were added. After $2 \mathrm{~h}$, the reaction was quenched by the addition of $\mathrm{HCl} 6 \mathrm{M}$, and the final solution was extracted with ethyl acetate. The organic layer was washed with $\mathrm{NaOH} 10 \%$ solution, dried, and evaporated, obtaining the final compound that was purified by recrystallization. 


\subsubsection{3-(Fur-2-ylcarbonyl)-8-methoxypyrazolo[1,5-a]quinazoline (6e)}

From 10 and furane. Pale yellow crystals, yield 20\%; TLC: toluene/ethyl acetate/acetic acid 8:2:2 $v / v / v ;$ IR $v \mathrm{~cm}^{-1} 1630 ;{ }^{1} \mathrm{H}-\mathrm{NMR}$ (DMSO-d 6 ) $\delta 9.25$ (s, 1H, H-5); 8.80 (s, 1H, H-2); 8.24 (d, 1H, H-6, $J=8.8 \mathrm{~Hz}) ; 8.06(\mathrm{~s}, 1 \mathrm{H}, \mathrm{H}-5$ furyl); $7.83(\mathrm{~d}, 1 \mathrm{H}, \mathrm{H}-9 \mathrm{~J}=2.0 \mathrm{~Hz}) ; 7.66(\mathrm{~d}, 1 \mathrm{H}, \mathrm{H}-3$ furyl,$J=3.6 \mathrm{~Hz}) ; 7.35$ $(\mathrm{dd}, 1 \mathrm{H}, \mathrm{H}-7, J=8.8 \mathrm{~Hz}, J=2.0 \mathrm{~Hz}) ; 6.77(\mathrm{~s}, 1 \mathrm{H}, \mathrm{H}-4$ furyl $) ; 4.04\left(\mathrm{~s}, 3 \mathrm{H}, \mathrm{OCH}_{3}\right) .{ }^{13} \mathrm{C}-\mathrm{NMR}\left(\mathrm{DMSO}^{-\mathrm{d}_{6}}\right) \delta$ 174.5, 154.2, 145.7, 138.0, 130.3, 118.7, 117.7, 113.9, 112.3, 111.8, 96.2, 56.4. ESI-MS calcd for $\mathrm{C}_{16} \mathrm{H}_{11} \mathrm{~N}_{3} \mathrm{O}_{3}$ (293.28); found: $m / z$ 293.88[M $+\mathrm{H}]^{+}$. Anal. $\mathrm{C}_{16} \mathrm{H}_{11} \mathrm{~N}_{3} \mathrm{O}_{3}(\mathrm{C}, \mathrm{H}, \mathrm{N})$.

\subsubsection{3-(1H-pyrrol-2-ylcarbonyl)-8-methoxypyrazolo[1,5-a]quinazoline (6f)}

From 10 and pyrrole. Cream crystals, yield 25\%; TLC: toluene/ethyl acetate/acetic acid 8:2:2 $v / v / v ;{ }^{1} \mathrm{H}-\mathrm{NMR}\left(\mathrm{CDCl}_{3}\right) \delta 12.31$ (bs, 1H, NH, exch.); 9.10 (s, 1H, H-5); 8.81 (s, 1H, H-2); 7.96 (d, 1H, $\mathrm{H}-6, J=8.8 \mathrm{~Hz}) ; 7.90(\mathrm{~d}, 1 \mathrm{H}, \mathrm{H}-9, J=2.0 \mathrm{~Hz}) ; 7.37(\mathrm{~m}, 1 \mathrm{H}, \mathrm{H}-3$ pyrrole); $7.22(\mathrm{dd}, 1 \mathrm{H}, \mathrm{H}-7, J=8.8 \mathrm{~Hz}$, $J=2.0 \mathrm{~Hz}) ; 7.16(\mathrm{~m}, 1 \mathrm{H}, \mathrm{H}-5$ pyrrole $) ; 6.39(\mathrm{~m} .1 \mathrm{H}, \mathrm{H}-4$ pyrrole $) ; 4.08\left(\mathrm{~s}, 3 \mathrm{H}, \mathrm{OCH}_{3}\right) .{ }^{13} \mathrm{C}-\mathrm{NMR}\left(\mathrm{CDCl}_{3}\right)$ $\delta 175.0,165.8,152.7,146.8,138.5,130.5,124.0,117.8,117.7,113.9,113.2,110.9,96.1,56.4$. ESI-MS calcd for $\mathrm{C}_{16} \mathrm{H}_{12} \mathrm{~N}_{4} \mathrm{O}_{2}$ (292.29); found: $m / z$ 292.99[M + H] $]^{+}$. Anal. $\mathrm{C}_{16} \mathrm{H}_{12} \mathrm{~N}_{4} \mathrm{O}_{2}(\mathrm{C}, \mathrm{H}, \mathrm{N})$.

\subsubsection{3-(1-Methyl-1H-pyrrol-2-ylcarbonyl)-8-methoxypyrazolo[1,5-a]quinazoline (6g)}

This product was obtained following the Friedel-Craft reaction from 10 and 1-methyl-1H-pyrrole, yield $10 \%$; or by the alkylation of $\mathbf{6 f}$ following the classical alkylation method: $0.15 \mathrm{mmol}$ of $\mathbf{6} \mathbf{f}$ in $3 \mathrm{~mL}$ of anhydrous DMF, $0.15 \mathrm{mmol}$ of $\mathrm{NaH}$, and $0.02 \mathrm{~mL}$ of MeI. The reaction was kept at $35^{\circ} \mathrm{C}$ for $1 \mathrm{~h}$, and the precipitate that was obtained by the addition of water was filtered and recrystallized by ethanol/water; yield 87\%. TLC: toluene/ethyl acetate/acetic acid 8:2:2 v/v/v; ${ }^{1} \mathrm{H}-\mathrm{NMR}\left(\mathrm{CDCl}_{3}\right) \delta 9.10$ (s, 1H, H-5); 8.51 (s, 1H, H-2); 7.91 (d, 1H, H-6, J = $8.8 \mathrm{~Hz}) ; 7.88$ (d, 1H, H-9, J = 2.4 Hz); 7.18 (dd, 1H, $\mathrm{H}-7, J=8.8 \mathrm{~Hz}, J=2.4 \mathrm{~Hz}) ; 7.01(\mathrm{dd}, 1 \mathrm{H}, \mathrm{H}-3$ pyrrole, $J=4.0 \mathrm{~Hz}, J=1.3 \mathrm{~Hz}) ; 7.16(\mathrm{~m}, 1 \mathrm{H}, \mathrm{H}-5$ pyrrole); 6.39 (dd. $1 \mathrm{H}, \mathrm{H}-4$ pyrrole, $J=4.0 \mathrm{~Hz}, J=2.8 \mathrm{~Hz}) ; 4.08\left(\mathrm{~s}, 3 \mathrm{H}, \mathrm{NCH}_{3}\right) ; 4.06\left(\mathrm{~s}, 3 \mathrm{H}, \mathrm{OCH}_{3}\right) .{ }^{13} \mathrm{C}-\mathrm{NMR}$ $\left(\mathrm{CDCl}_{3}\right) \delta 179.2,165.9,155.4,145.5,130.0,128.9,120.8,117.3,107.5,106.4,55.8,37.8$; ESI-MS calcd for $\mathrm{C}_{17} \mathrm{H}_{14} \mathrm{~N}_{4} \mathrm{O}_{2}$ (306.32); found: $m / z$ 307.02[M+ H] $]^{+}$. Anal. $\mathrm{C}_{17} \mathrm{H}_{14} \mathrm{~N}_{4} \mathrm{O}_{2}(\mathrm{C}, \mathrm{H}, \mathrm{N})$.

\subsection{8-Methoxypyrazolo[1,5-a]quinazolin-5(4H)-one (7)}

The decarboxylation of the ethyl 8-methoxy-5-oxo-4,5-dihydropyrazolo[1,5-a]quinazoline 3-carboxylate [18] (1.0 mmol) was obtained in $\mathrm{H}_{3} \mathrm{PO}_{4}$ at fusion condition. After that starting material disappeared in TLC (toluene/ethyl acetate/methanol 8:2:1.5 $v / v / v$ as eluent), the treatment with ice/water gave a precipitate that was isolated and purified by recrystallization with ethanol. Cream crystals, yield 80\%; IR $v \mathrm{~cm}^{-1}$ 3137, 1697; ${ }^{1} \mathrm{H}-\mathrm{NMR}$ (DMSO-d $\left.\mathrm{d}_{6}\right) \delta 12.05$ (bs, $1 \mathrm{H}, \mathrm{NH}$, exch.); $8.02(\mathrm{~d}, 1 \mathrm{H}$, $\mathrm{H}-6, J=8.8 \mathrm{~Hz}) ; 7.76(\mathrm{~d}, 1 \mathrm{H}, \mathrm{H}-2, J=2.0 \mathrm{~Hz}) ; 7.47(\mathrm{~d}, \mathrm{H}-9, J=2.4 \mathrm{~Hz}) ; 7.02(\mathrm{dd}, 1 \mathrm{H}, \mathrm{H}-7, J=8.8 \mathrm{~Hz}$, $J=2.4 \mathrm{~Hz}) ; 5.87(\mathrm{~d}, 1 \mathrm{H}, \mathrm{H}-3, J=2.0 \mathrm{~Hz}) ; 3.92\left(\mathrm{~s}, 3 \mathrm{H}, \mathrm{OCH}_{3}\right)$. ESI-MS calcd for $\mathrm{C}_{11} \mathrm{H}_{9} \mathrm{~N}_{3} \mathrm{O}_{2}(215.21)$; found: $m / z$ 215.91[M $+\mathrm{H}]^{+}$. Anal. $\mathrm{C}_{11} \mathrm{H}_{9} \mathrm{~N}_{3} \mathrm{O}_{2}(\mathrm{C}, \mathrm{H}, \mathrm{N})$.

\subsection{8-Methoxypyrazolo[1,5-a]quinazoline (8)}

From 7 , following the same procedure described for the synthesis of $5 \mathbf{a}-\mathbf{e}$. White crystals by ethanol; yield 85\%. ${ }^{1} \mathrm{H}-\mathrm{NMR}\left(\mathrm{DMSO}_{\mathrm{d}}\right)$ ) $\delta 8.95(\mathrm{~s}, 1 \mathrm{H}, \mathrm{H}-5) ; 8.16(\mathrm{~d}, 1 \mathrm{H}, \mathrm{H}-2, J=2.2 \mathrm{~Hz}), 8.11(\mathrm{~d}, 1 \mathrm{H}$, $\mathrm{H}-6, J=8.8 \mathrm{~Hz}) ; 7.75(\mathrm{~d}, 1 \mathrm{H}, \mathrm{H}-9, J=2.4 \mathrm{~Hz}) ; 7.22(\mathrm{dd}, 1 \mathrm{H}, \mathrm{H}-7, J=8.8 \mathrm{~Hz}, J=2.4 \mathrm{~Hz}) ; 6.77$ (d, 1H, H-3, $J=2.2 \mathrm{~Hz}) ; 3.99\left(\mathrm{~s}, 3 \mathrm{H}, \mathrm{OCH}_{3}\right)$. ESI-MS calcd for $\mathrm{C}_{11} \mathrm{H}_{9} \mathrm{~N}_{3} \mathrm{O}(199,21)$; found: $m / z$ 199.81[M + H] ${ }^{+}$. Anal. $\mathrm{C}_{11} \mathrm{H}_{9} \mathrm{~N}_{3} \mathrm{O}(\mathrm{C}, \mathrm{H}, \mathrm{N})$.

\subsection{General Procedure for the Synthesis of $\mathbf{9 a}, \mathbf{b}$}

A solution of starting material $8(0.35 \mathrm{mmol})$ in dichloromethane $(5 \mathrm{~mL})$ was supplemented with an excess of bromine $(0.8 \mathrm{~mL})$ to obtain compound $9 \mathbf{a}$ or $N$-iodosucinimide (NIS, 1:2) for final product 
9b. The final solution was evaporated to dryness, and the residue was recovered with $10 \% \mathrm{NaOH}$ solution, filtered, and washed with water. The raw compound was recrystallized by a suitable solvent.

3.12.1. 3-Bromo-8-methoxypyrazolo[1,5-a]quinazoline (9a)

From 5e and bromine; yield 85\%; ${ }^{1} \mathrm{H}-\mathrm{NMR}\left(\mathrm{DMSO}_{\mathrm{d}}\right)$ ): $\delta 9.03(\mathrm{~s}, 1 \mathrm{H}, \mathrm{H}-5) ; 8.33(1,1 \mathrm{H}, \mathrm{H}-2), 8.16$ (d, 1H, H-6, J = 8.8 Hz); 7.73 (d, 1H, H-9, J = 2.4 Hz); 7.26 (dd, 1H, H-7, J = 8.8 Hz, J = 2.4 Hz); 4.00 $\left(\mathrm{s}, 3 \mathrm{H}, \mathrm{OCH}_{3}\right) .{ }^{13} \mathrm{C}-\mathrm{NMR}\left(\mathrm{DMSO}_{6} \mathrm{~d}_{6}\right) \delta 155.4,133.6,128.9,120.8,106.4,91.9,55.8$. ESI-MS calcd for $\mathrm{C}_{11} \mathrm{H}_{8} \mathrm{~N}_{3} \mathrm{OBr}(278.10)$ found: $m / z 278.7[\mathrm{M}+\mathrm{H}]^{+}$. Anal. $\mathrm{C}_{11} \mathrm{H}_{8} \mathrm{~N}_{3} \mathrm{OBr}(\mathrm{C}, \mathrm{H}, \mathrm{N})$. Anal $\mathrm{C}, \mathrm{H}, \mathrm{N}$.

\subsubsection{3-Iodo-8-methoxypyrazolo[1,5-a]quinazoline (9b)}

From 5e and NIS; white crystals; yield 85\%. ${ }^{1} \mathrm{H}-\mathrm{NMR}\left(\mathrm{DMSO}_{\mathrm{d}}\right)$ ) $\delta 9.09$ (s, 1H, H-5); 8.27 (s, $1 \mathrm{H}$, $\mathrm{H}-2), 8.15(\mathrm{~d}, 1 \mathrm{H}, \mathrm{H}-6, J=8.8 \mathrm{~Hz}) ; 7.73(\mathrm{~d}, 1 \mathrm{H}, \mathrm{H}-9, J=2.2 \mathrm{~Hz}) ; 7.25(\mathrm{dd}, 1 \mathrm{H}, \mathrm{H}-7, J=8.8 \mathrm{~Hz}, J=2.2 \mathrm{~Hz})$; $4.00\left(\mathrm{~s}, 3 \mathrm{H}, \mathrm{OCH}_{3}\right) .{ }^{13} \mathrm{C}-\mathrm{NMR}\left(\mathrm{DMSO}_{-} \mathrm{d}_{6}\right) \delta 155.4,138.1,128.9,120.8,117.3,106.4,56.3,55.8$. ESI-MS calcd for $\mathrm{C}_{11} \mathrm{H}_{8} \mathrm{~N}_{3} \mathrm{OI}$ (325.11); found: $m / z$ 325.71[M + H] $]^{+}$. Anal. $\mathrm{C}_{11} \mathrm{H}_{8} \mathrm{~N}_{3} \mathrm{OI}(\mathrm{C}, \mathrm{H}, \mathrm{N})$.

\subsection{General Procedure for the Synthesis of $\mathbf{1 1 a}, \mathbf{b}, \mathbf{d}-\mathbf{g}$}

$\mathrm{NaBH}_{3} \mathrm{CN}(0.5 \mathrm{mmol})$ was added to a solution of starting material, $\mathbf{6 a}, \mathbf{b}, \mathbf{d}-\mathbf{g}(0.15 \mathrm{mmol})$, in glacial acetic acid $(5 \mathrm{~mL})$; the mixture was maintained at $50{ }^{\circ} \mathrm{C}$ for $1 \mathrm{~h}$, and the reaction was monitored by TLC (toluene/ethyl acetate/methanol 8:2:1.5 $v / v / v$ as eluent). When the starting material disappeared, the mixture was cooled and water was added; the precipitate was collected by filtration and purified by recrystallization.

\subsubsection{3-(2-Methoxyphenylcarbonyl)-8-methoxy-4,5-dihydropyrazolo[1,5-a]quinazoline (11a)}

From 6a, pale cream crystals, yield 68\%; IR $v \mathrm{~cm}^{-1} 3404,1639 ;{ }^{1} \mathrm{H}-\mathrm{NMR}\left(\mathrm{DMSO}-\mathrm{d}_{6}\right.$ ) $\delta 7.82$ (bs, $1 \mathrm{H}$, $\mathrm{NH}$, exch.); $7.44(\mathrm{t}, 1 \mathrm{H}, \mathrm{H}-4$ phenyl, $J=8.4 \mathrm{~Hz}) ; 7.32(\mathrm{~s}, 1 \mathrm{H}, \mathrm{H}-2) ; 7.27(\mathrm{~d}, 1 \mathrm{H}, \mathrm{H}-6$ phenyl, $J=7.6 \mathrm{~Hz}) ;$ $7.20(\mathrm{~d}, 1 \mathrm{H}, \mathrm{H}-6, J=8.4 \mathrm{~Hz}) ; 7.12(\mathrm{~d}, 1 \mathrm{H}, \mathrm{H}-3$ phenyl, $J=8.4 \mathrm{~Hz}) ; 7.05(\mathrm{~d}, \mathrm{H}-9, J=2.0 \mathrm{~Hz}) ; 7.04$ (t, 1H, $\mathrm{H}-5$ phenyl, $J=7.6 \mathrm{~Hz}) ; 6.74(\mathrm{dd}, 1 \mathrm{H}, \mathrm{H}-7, J=8.4 \mathrm{~Hz}, J=2.0 \mathrm{~Hz}) ; 4.52\left(\mathrm{~s}, 2 \mathrm{H}, \mathrm{CH}_{2}\right) ; 3.75\left(\mathrm{~s}, 3 \mathrm{H}, 8-\mathrm{OCH}_{3}\right)$; $3.74\left(\mathrm{~s}, 3 \mathrm{H}, \mathrm{OCH}_{3}\right) .{ }^{13} \mathrm{C}-\mathrm{NMR}\left(\mathrm{DMSO}_{6} \mathrm{~d}_{6}\right) \delta 196.3,160.1,149.6,141.7,134.7,133.6,130.9,127.3,126.6$, $123.9,117.4,114.4,112.2,111.7,104.6,99.6,55.6,42.4$. ESI-MS calcd for $\mathrm{C}_{19} \mathrm{H}_{17} \mathrm{~N}_{3} \mathrm{O}_{3}$ (335,36); found: $m / z 335.96[\mathrm{M}+\mathrm{H}]^{+}$. Anal. $\mathrm{C}_{19} \mathrm{H}_{17} \mathrm{~N}_{3} \mathrm{O}_{3}(\mathrm{C}, \mathrm{H}, \mathrm{N})$.

\subsubsection{3-(Thien-2-ylcarbonyl)-8-methoxy-4,5-dihydropyrazolo[1,5-a]quinazoline (11b)}

From 6b, pale yellow crystals, yield 74\%; IR $v \mathrm{~cm}^{-1} 3430,1640 ;{ }^{1} \mathrm{H}-\mathrm{NMR}\left(\mathrm{DMSO}-\mathrm{d}_{6}\right) \delta 8.19(\mathrm{~s}, 1 \mathrm{H}$, $\mathrm{H}-2) ; 7.96$ (d, 1H, H-3 thienyl, J = 3.2 Hz); 7.91 (d, 1H, H-5 thienyl, J = 4.4 Hz); 7.84 (bs, $1 \mathrm{H}, \mathrm{NH}$, exch.); $7.23(\mathrm{~m} 2 \mathrm{H}, \mathrm{H}-6$ and H-4 thienyl); $7.10(\mathrm{~d}, 1 \mathrm{H}, \mathrm{H}-9 \mathrm{~J}=2.0 \mathrm{~Hz}) ; 6.76(\mathrm{~d}, 1 \mathrm{H}, \mathrm{H}-7, J=8.4) ; 4.53(\mathrm{~s}, 2 \mathrm{H}$, $\left.\mathrm{CH}_{2}\right) ; 3.77\left(\mathrm{~s}, 3 \mathrm{H}, \mathrm{OCH}_{3}\right) .{ }^{13} \mathrm{C}-\mathrm{NMR}\left(\mathrm{DMSO}_{6} \mathrm{~d}_{6}\right) \delta 177.9,159.7,150.4,144.5,141.3,134.2,132.0,131.3$, 129.6, 128.2, 112.6, 111.9, 103.3, 99.8, 55.9, 42.2.. ESI-MS calcd for $\mathrm{C}_{16} \mathrm{H}_{13} \mathrm{~N}_{3} \mathrm{O}_{2} \mathrm{~S}(311,36)$; found: $\mathrm{m} / z$ 312.06[M+ H $]^{+}$. Anal. $\mathrm{C}_{16} \mathrm{H}_{13} \mathrm{~N}_{3} \mathrm{O}_{2} \mathrm{~S}(\mathrm{C}, \mathrm{H}, \mathrm{N})$.

\subsubsection{3-(4-Methoxyphenylcarbonyl)-8-methoxy-4,5-dihydropyrazolo[1,5-a]quinazoline (11d)}

From 6d, pale cream crystals, yield 50\%; IR $v \mathrm{~cm}^{-1} 3317,1633 ;{ }^{1} \mathrm{H}-\mathrm{NMR}\left(\mathrm{DMSO}-\mathrm{d}_{6}\right) \delta 7.82(\mathrm{~m}, 2 \mathrm{H}$, $\mathrm{H}-2$ and NH exch.); 7.77 (d, 2H, H-2, and H-6 phenyl, $J=8.0 \mathrm{~Hz}) ; 7.21(\mathrm{~d}, 1 \mathrm{H}, \mathrm{H}-6, J=8.4 \mathrm{~Hz}) ; 7.10$ (s, 1H, H-9); 7.04 (d, 2H, H-3, and H-5 phenyl, $J=8.0 \mathrm{~Hz}) ; 6.75$ (d, 1H, H-7, J = 6.8 Hz); 4.53 (s, 2H, $\left.\mathrm{CH}_{2}\right) ; 3.82\left(\mathrm{~s}, 3 \mathrm{H}, 8-\mathrm{OCH}_{3}\right) ; 3.76\left(\mathrm{~s}, 3 \mathrm{H}, \mathrm{OCH}_{3}\right) .{ }^{13} \mathrm{C}-\mathrm{NMR}\left(\mathrm{DMSO}_{6} \mathrm{~d}_{6}\right) \delta 187.1,165.3,163.2,154.5,145.9$, 142.6, 137.7, 130.5, 128.4, 117.3, 114.3, 113.8, 111.7, 99.67, 56.8, 55.9, 42.0. ESI-MS calcd for $\mathrm{C}_{19} \mathrm{H}_{17} \mathrm{~N}_{3} \mathrm{O}_{3}$ (335,36); found: $m / z$ 334.76[M + H] $]^{+}$. Anal. $\mathrm{C}_{19} \mathrm{H}_{17} \mathrm{~N}_{3} \mathrm{O}_{3}(\mathrm{C}, \mathrm{H}, \mathrm{N})$. 
3.13.4. 3-(Fur-2-ylcarbonyl)-8-methoxy-4,5-dihydropyrazolo[1,5-a]quinazoline (11e)

From 6e, pale yellow crystals, yield $80 \%$; IR $v \mathrm{~cm}^{-1} 3325,1680 ;{ }^{1} \mathrm{H}-\mathrm{NMR}\left(\mathrm{CDCl}_{3}\right) \delta 8.25(\mathrm{~s}, 1 \mathrm{H}$, H-2); 7.63 (s, 1H, H-5 furyl); 7.27 (m, 2H, H-9 and H-3 furyl); 7.17 (bs, 1H, NH exch.); 7.02 (d, 1H, H-6, $J=8.4 \mathrm{~Hz}) ; 6.70(\mathrm{dd}, 1 \mathrm{H}, \mathrm{H}-7, J=8.8 \mathrm{~Hz}, J=2.0 \mathrm{~Hz}) ; 6.57(\mathrm{~m}, 1 \mathrm{H}, \mathrm{H}-4$ furyl $) ; 4.67\left(\mathrm{~s}, 2 \mathrm{H}, \mathrm{CH}_{2}\right) ; 3.85$ $\left(\mathrm{s}, 3 \mathrm{H}, \mathrm{OCH}_{3}\right) .{ }^{13} \mathrm{C}-\mathrm{NMR}\left(\mathrm{CDCl}_{3}\right) \delta 142.0,130.4,127.4,117.8,116.0,112.2,112.1,99.7,55.6,42.4$. ESI-MS calcd for $\mathrm{C}_{16} \mathrm{H}_{13} \mathrm{~N}_{3} \mathrm{O}_{3}$ (295.29); found: $m / z$ 295.99[M + H] $]^{+}$. Anal. $\mathrm{C}_{16} \mathrm{H}_{13} \mathrm{~N}_{3} \mathrm{O}_{3}(\mathrm{C}, \mathrm{H}, \mathrm{N})$.

3.13.5. 3-(1H-pyrrol-2-ylcarbonyl)-8-methoxy-4,5-dihydropyrazolo[1,5-a]quinazoline (11f)

From 6f; yield 25\%; IR v cm ${ }^{-1} 3354,1682 ;{ }^{1} \mathrm{H}-\mathrm{NMR}\left(\mathrm{CDCl}_{3}\right) \delta 9.54$ (bs, $1 \mathrm{H}, \mathrm{NH}$ pyrrole, exch.); 8.01 (s, 1H, H-2); 7.29 (d, 1H, H-9, J = 2.0 Hz); 7.03 (m, 4H, H-6, NH exch., H-3 and H-5 pyrrole); 6.70 $(\mathrm{dd}, 1 \mathrm{H}, \mathrm{H}-7, J=8.8 \mathrm{~Hz}, J=2.0 \mathrm{~Hz}) ; 6.36(\mathrm{~m} .1 \mathrm{H}, \mathrm{H}-4$ pyrrole $) ; 4.65\left(\mathrm{~s}, 2 \mathrm{H}, \mathrm{CH}_{2}\right) ; 3.86\left(\mathrm{~s}, 3 \mathrm{H}, \mathrm{OCH}_{3}\right)$. ${ }^{13} \mathrm{C}-\mathrm{NMR}\left(\mathrm{CDCl}_{3}\right) \delta 178.8,160.1,149.6$ 141.7, 134.7, 130.9, 129.6, 127.3, 117.4, 112.2, 111.7, 108.0, 104.6, 99.6, 55.6, 42.4. ESI-MS calcd for $\mathrm{C}_{16} \mathrm{H}_{14} \mathrm{~N}_{4} \mathrm{O}_{2}$ (294.31); found: $m / z 293.61[\mathrm{M}+\mathrm{H}]^{+}$. Anal. $\mathrm{C}_{16} \mathrm{H}_{14} \mathrm{~N}_{4} \mathrm{O}_{2}$ $(\mathrm{C}, \mathrm{H}, \mathrm{N})$.

\subsubsection{3-(1-Methyl-1H-pyrrol-2-ylcarbonyl)-8-methoxypyrazolo[1,5-a]quinazoline (11g)}

From 6g; yield 70\%. ${ }^{1} \mathrm{H}-\mathrm{NMR}\left(\mathrm{CDCl}_{3}\right) \delta 7.85(\mathrm{~s}, 1 \mathrm{H}, \mathrm{H}-2) ; 7.27(\mathrm{~d}, 1 \mathrm{H}, \mathrm{H}-9, \mathrm{~J}=2.4 \mathrm{~Hz}) ; 7.00(\mathrm{~m}, 2 \mathrm{H}$, H-6 and NH exch.); 6.91 (m, 1H, H-3 pyrrole); 7.16 (m, 1H, H-5 pyrrole); 6.69 (d, 1H, H-7, J = 8.8); 6.17 (m. 1H, H-4 pyrrole); $4.62\left(\mathrm{~s}, 2 \mathrm{H}, \mathrm{CH}_{2}\right) ; 3.93\left(\mathrm{~s}, 3 \mathrm{H}, \mathrm{NCH}_{3}\right) ; 3.85\left(\mathrm{~s}, 3 \mathrm{H}, \mathrm{OCH}_{3}\right) .{ }^{13} \mathrm{C}-\mathrm{NMR}\left(\mathrm{CDCl}_{3}\right) \delta$ 178.8, 160.1, 149.6, 141.7, 134.7, 130.9, 129.5, 127,3, 117.3, 112.2, 111.7, 108.0, 104.6, 99.6, 55.6, 42.4, 36.8; ESI-MS calcd for $\mathrm{C}_{17} \mathrm{H}_{16} \mathrm{~N}_{4} \mathrm{O}_{2}$ (308.33); found: $m / z$ 308.93[M + H] $]^{+}$. Anal. $\mathrm{C}_{17} \mathrm{H}_{16} \mathrm{~N}_{4} \mathrm{O}_{2}(\mathrm{C}, \mathrm{H}, \mathrm{N})$.

\subsection{Radioligand Binding Assay}

$\left[{ }^{3} \mathrm{H}\right]$ Ro15-1788 (specific activity 78.8 Ci/mmol) was obtained from Perkin Elmer. All of the other chemicals, which were of reagent grade, were obtained from commercial suppliers. Bovine cerebral cortex membranes were prepared as previously described [28,29]. The membrane preparations were diluted with $50 \mathrm{mM}$ of tris-citrate buffer $\mathrm{pH}$ 7.4, and used in the binding assay. Protein concentration was assayed using the method of Lowry et al. [30]. $\left[{ }^{3} \mathrm{H}\right]$ Ro $15-1788$ binding studies were performed as previously reported [21]. At least six different concentrations of each compound were used. The data of $n=5$ experiments carried out in triplicate were analyzed by means of an iterative curve-fitting procedure (program Prism, GraphPad, San Diego, CA), which provided $\mathrm{IC}_{50}, \mathrm{Ki}$, and SEM values for tested compounds, the Ki values being calculated from the Cheng and Prusoff equation [31].

\subsection{General Methods for Electrophysiological Assays}

\subsubsection{Expression of Human Receptor Subunits}

A mixture of pCDM8-based vectors for the $\alpha_{1}, \beta_{2}$, or $\gamma_{2 L}$ subunits of human $\mathrm{GABA}_{\mathrm{A}}$ receptors (total of 1.5 ng of DNA, comprising equal amounts of $\alpha, \beta$, and $\gamma$ subunit vectors), or equal amounts of $\alpha$ and $\beta$ receptors for the expression of $\alpha_{1} \beta_{2}$ receptors, were injected into the animal pole of $X$. laevis oocytes as described [32] with the use of a microdispenser (Drummond Scientific, Broomwall, PA). The injected oocytes were maintained at $13^{\circ} \mathrm{C}$ in sterile modified Barth's solution [MBS: $88 \mathrm{mM}$ $\mathrm{NaCl}, 1 \mathrm{mM} \mathrm{KCl}, 10 \mathrm{mM}$ HEPES-NaOH (pH 7.5), $0.82 \mathrm{mM} \mathrm{MgSO}_{4}, 2.4 \mathrm{mM} \mathrm{NaHCO}_{3}, 0.91 \mathrm{mM} \mathrm{CaCl}_{2}$, $\left.0.33 \mathrm{mM} \mathrm{Ca}\left(\mathrm{NO}_{3}\right)_{2}\right]$ supplemented with streptomycin $(10 \mathrm{mg} / \mathrm{L})$, penicillin $(10,000 \mathrm{U} / \mathrm{L})$, gentamicin $(50 \mathrm{mg} / \mathrm{L})$, theophylline $(90 \mathrm{mg} / \mathrm{L})$, and pyruvate $(220 \mathrm{mg} / \mathrm{L})$.

\subsubsection{Electrophysiology}

Electrophysiological measurements were performed in oocytes 2 to 4 days after DNA injection. Oocytes were placed in a rectangular chamber (volume $\sim 100 \mu \mathrm{L}$ ) and perfused at a rate of $1.7 \mathrm{~mL} / \mathrm{min}$ with MBS at room temperature with the use of a roller pump (Cole-Parmer, Chicago, IL) and 18-gauge 
polyethylene tubing (Clay Adams, Parsippany, NJ, USA). Oocytes were impaled at the animal pole with two glass electrodes ( 0.5 to $10 \mathrm{M} \Omega$ ) filled with $3 \mathrm{M}$ of $\mathrm{KCl}$, and were clamped at $-70 \mathrm{mV}$ with the use of an oocyte clamp (model OC725C; Warner Instruments, Hamden, CT). Currents were measured and analyzed with the pClamp 9.2 software (Molecular Devices, Union City, CA, USA). GABA (Sigma, St. Louis, MO, USA) was dissolved in MBS and applied to the oocytes for $30 \mathrm{~s}$. Oocytes were perfused with test drugs for $30 \mathrm{~s}$ either in the absence of the agonists or in its presence at the $\mathrm{EC}_{5-10}$ (the concentration of agonist that induces a peak current equal to $5-10 \%$ of the maximal current elicited by the maximal concentration of the agonist). Compounds were first dissolved in DMSO at a concentration of $10 \mathrm{mM}$, and then diluted in MBS to the final concentrations. In each experiment, control responses were determined before and 10/15 min after application of the drug.

\subsubsection{Statistics}

Statistical analysis was performed on normalized data using the Kruskal-Wallis test followed by Dunn's post hoc test or the Mann-Whitney test using GraphPad Prism 7 (Graph Pad Software, Inc., San Diego, CA, USA).

\section{Conclusions}

In this paper, new 8-methoxypyrazolo[1,5-a]quinazolines bearing at position 3 of the (hetero)aryl group (type 5 compounds) or (hetero)aroyl moiety (type 6 compounds) and their corresponding 4,5-dihydroderivatives (type $\mathbf{1 1}$ compounds) were synthesized and evaluated for their ability to modulate the recombinant $\alpha_{1} \beta_{2} \gamma_{2 L} G_{A B A}$ receptors. Compounds that showed a certain modulation of chlorine current are 3-(hetero)aroylpyrazolo[1,5-a]quinazolines, and $\mathbf{6 a}$ and $\mathbf{6} \mathbf{b}$ were the most representative compounds. These products modulate the $\mathrm{GABA}_{\mathrm{A}} \mathrm{R}$ in an opposite manner, suggesting that $\mathbf{6 b}$ acts as partial agonist and $\mathbf{6 a}$ acts as an inverse partial agonist.

Among the 3-(hetero)aroyl derivatives with the 4,5-dihydropyrazolo[1,5-a]quinazoline scaffold, the most interesting compound was 11d, for which an effect on the chlorine current is measurable at $\geq 0.01 \mu \mathrm{M}$. This compound will be the object of further studies.

Finally, we found the profile of the null modulator $6 \mathrm{~g}$ interesting, since it not only acts as an antagonist blocking the potentiation of the GABAergic function induced by diazepam (so interacting at the high-affinity benzodiazepine site located in the extracellular domain at the $\alpha+/ \beta-$ [2]), but it also works as a positive allosteric modulator at the low-affinity site located in the extracellular domain at the $\alpha+/ \beta$ - interface. These results suggest that this compound could act to both the high-affinity and the low-affinity benzodiazepine site, so we can hypothesize that it will display a much broader action than the classic high-affinity benzodiazepine site ligands.

Moreover, since $6 \mathrm{~g}$ is the first compound acting via the $\alpha+/ \beta-$ interface of $\mathrm{GABA}_{\mathrm{A}}$ receptors with the PQ scaffold, it may represent an interesting lead for the discovery of a new class of ligand, which would be useful for the study of this recently discovered low-affinity benzodiazepine site.

Supplementary Materials: Supplementary materials can be found at http:/ / www.mdpi.com/1422-0067/20/6/ 1438/s1.

Author Contributions: G.G. designed the compounds and wrote the manuscript; N.C., L.C., M.P.G., and C.V. synthesized the compounds and checked the final version of manuscript. In vitro studies were performed by S.D. and C.M. (inhibition data); M.P.M. designed and performed the electrophysiological experiments, analyzed the data, and wrote the pharmacological section. All of the authors have given approval to the final version of the manuscript.

Funding: This work was financially supported by the Ministero dell'Istruzione dell'Università e Ricerca (MIUR).

Conflicts of Interest: The authors declare no conflict of interest. 


\section{Abbreviations}

$\begin{array}{ll}\text { GABA }_{A} R & \text { GABA receptors Type A } \\ \text { GABA }_{B} R & \text { GABA receptor Type B } \\ \text { GPCR } & \text { G-protein-coupled receptors } \\ \text { LGIC } & \text { ligand gated ion channel } \\ \text { PQ } & \text { pyrazoloquinazoline } \\ \text { PBTs } & \text { pyrazolobenzotriazines } \\ \text { PPs } & \text { pyrazolopyrimidines } \\ \text { PTs } & \text { pyrazolotriazines }\end{array}$

\section{References}

1. Avoli, M.; D'Antuono, M.; Louvel, J.; Kohling, R.; Biagini, G.; Pumain, R.; D'Arcangelo, G.; Tancredi, V. Network and pharmacological mechanisms leading to epileptiform synchronization in the limbic system in vitro. Prog. Neurobiol. 2002, 68, 167-207. [CrossRef]

2. Alexander, S.P.; Peters, J.A.; Kelly, E.; Marrion, N.V.; Faccenda, E.; Harding, S.D.; Pawson, A.J.; Sharman, J.L.; Southan, C.; Davies, J.A.; et al. THE CONCISE GUIDE TO PHARMACOLOGY 2017/18: Ligand-gated ion channels. Br. J. Pharmacol. 2017, 174 (Suppl. 1), S130-S159. [CrossRef]

3. Chua, H.C.; Chebib, M. Chapter One-GABAA Receptors and the Diversity in their Structure and Pharmacology. Adv. Pharmacol. 2017, 79, 1-34. [CrossRef] [PubMed]

4. Sieghart, W.; Savić, M.M. International Union of Basic and Clinical Pharmacology. CVI: GABAA Receptor Subtype- and Function-selective Ligands: Key Issues in Translation to Humans. Pharmacol. Rev. 2018, 70, 836-878. [CrossRef] [PubMed]

5. Krall, J.; Balle, T.; Krogsgaard-Larsen, N.; Sørensen, T.E.; Krogsgaard-Larsen, P.; Kristiansen, U.; Frølund, B. Chapter Eight-GABAA Receptor Partial Agonists and Antagonists: Structure, Binding Mode, and Pharmacology. Adv. Pharmacol. 2015, 72, 201-227. [CrossRef] [PubMed]

6. Feng, H.-J.; Forman, S.A. Comparison of $\alpha \beta \delta$ and $\alpha \beta \gamma$ GABAA receptors: Allosteric modulation and identification of subunit arrangement by site-selective general anesthetics. Pharmacol. Res. 2018, 133, 289-300. [CrossRef] [PubMed]

7. Baur, R.; Tan, K.R.; Lüscher, B.P.; Gonthier, A.; Goeldner, M.; Sigel, E. Covalent modification of GABA A receptor isoforms by a diazepam analogue provides evidence for a novel benzodiazepine binding site that prevents modulation by these drugs. J. Neurochem. 2008, 106, 2353-2363. [CrossRef]

8. Ramerstorfer, J.; Furtmüller, R.; Sarto-Jackson, I.; Varagic, Z.; Sieghart, W.; Ernst, M. The GABAA receptor alpha+beta- interface: A novel target for subtype selective drugs. J. Neurosci. 2011, 31, 870-877. [CrossRef]

9. Sieghart, W.; Ramerstorfer, J.; Sarto-Jackson, I.; Varagic, Z.; Ernst, M. A novel GABAA receptor pharmacology: Drugs interacting with the $\alpha+\beta$ - interface. Br. J. Pharmacol. 2012, 166, 476-485. [CrossRef]

10. Walters, R.J.; Hadley, S.H.; Morris, K.D.; Amin, J. Benzodiazepines act on GABAA receptors via two distinct and separable mechanisms. Nat. Neurosci. 2000, 3, 1274-1281. [CrossRef] [PubMed]

11. Varagic, Z.; Wimmer, L.; Schnürch, M.; Mihovilovic, M.D.; Huang, S.; Rallapalli, S.; Cook, J.M.; Mirheydari, P.; Ecker, G.F.; Sieghart, W.; et al. Identification of novel positive allosteric modulators and null modulators at the GABAA receptor $\alpha+\beta$ - interface. Br. J. Pharmacol. 2013, 169, 371-383. [CrossRef] [PubMed]

12. Simeone, X.; Siebert, D.C.B.; Bampali, K.; Varagic, Z.; Treven, M.; Rehman, S.; Pyszkowski, J.; Holzinger, R.; Steudle, F.; Scholze, P.; et al. Molecular tools for GABAAreceptors: High affinity ligands for $\beta 1$-containing subtypes. Sci. Rep. 2017, 7, 1-12. [CrossRef] [PubMed]

13. Mascia, M.P.; Ledda, G.; Orrù, A.; Marongiu, A.; Loriga, G.; Maciocco, E.; Biggio, G.; Ruiu, S. Differential modulation of GABAA receptor function by aryl pyrazoles. Eur. J. Pharmacol. 2014, 733, 1-6. [CrossRef]

14. Varagic, Z.; Ramerstorfer, J.; Huang, S.; Rallapalli, S.; Sarto-Jackson, I.; Cook, J.; Sieghart, W.; Ernst, M. Subtype selectivity of $\alpha+\beta$ - site ligands of GABAA receptors: Identification of the first highly specific positive modulators at $\alpha 6 \beta 2 / 3 \gamma 2$ receptors. Br. J. Pharmacol. 2013, 169, 384-399. [CrossRef] [PubMed]

15. Knutson, D.E.; Kodali, R.; Divović, B.; Treven, M.; Stephen, M.R.; Zahn, N.M.; Dobričić, V.; Huber, A.T.; Meirelles, M.A.; Verma, R.S.; et al. Design and Synthesis of Novel Deuterated Ligands Functionally Selective for the $\gamma$-Aminobutyric Acid Type A Receptor (GABA A R) $\alpha 6$ Subtype with Improved Metabolic Stability and Enhanced Bioavailability. J. Med. Chem. 2018, 61, 2422-2446. [CrossRef] [PubMed] 
16. Miller, P.S.; Aricescu, A.R. Crystal structure of a human GABAA receptor. Nature 2014, 512, $270-275$. [CrossRef] [PubMed]

17. Zhu, S.; Noviello, C.M.; Teng, J.; Walsh, R.M.; Kim, J.J.; Hibbs, R.E. Structure of a human synaptic GABAA receptor. Nature 2018, 559, 67-88. [CrossRef]

18. Guerrini, G.; Ciciani, G.; Crocetti, L.; Daniele, S.; Ghelardini, C.; Giovannoni, M.P.; Iacovone, A.; Di Cesare Mannelli, L.; Martini, C.; Vergelli, C. Identification of a New Pyrazolo[1,5-a ]quinazoline Ligand Highly Affine to $\gamma$-Aminobutyric Type A (GABAA ) Receptor Subtype with Anxiolytic-Like and Antihyperalgesic Activity. J. Med. Chem. 2017, 60, 9691-9702. [CrossRef]

19. Lemon, M.; Strain, J.D.; Hegg, A.M.; Farver, D.K. Indiplon in the management of insomnia. Drug Des. Dev. Ther. 2009, 3, 131. [CrossRef]

20. Skolnick, P. Anxioselective anxiolytics: On a quest for the Holy Grail. Trends Pharmacol. Sci. 2012, 33, 611-620. [CrossRef]

21. Costanzo, A.; Guerrini, G.; Ciciani, G.; Bruni, F.; Selleri, S.; Costa, B.; Martini, C.; Lucacchini, A.; Malmberg Aiello, P.; Ipponi, A. Benzodiazepine receptor ligands. 4. Synthesis and pharmacological evaluation of 3-heteroaryl-8-chloropyrazolo[5,1-c][1,2,4]benzotriazine 5-oxides. J. Med. Chem. 1999, 42, 2218-2226. [CrossRef] [PubMed]

22. Guerrini, G.; Ciciani, G.; Daniele, S.; Di Cesare Mannelli, L.; Ghelardini, C.; Martini, C.; Selleri, S. Synthesis and pharmacological evaluation of pyrazolo[1,5-a]pyrimidin-7(4H)-one derivatives as potential GABAA-R ligands. Bioorg. Med. Chem. 2017, 25, 1901-1906. [CrossRef] [PubMed]

23. Guerrini, G.; Ciciani, G.; Daniele, S.; Martini, C.; Costagli, C.; Guarino, C.; Selleri, S. A new class of pyrazolo[5,1-c][1,2,4]triazines as $\gamma$-aminobutyric type A (GABAA) receptor subtype ligand: Synthesis and pharmacological evaluation. Bioorg. Med. Chem. 2018. [CrossRef] [PubMed]

24. Guerrini, G.; Ciciani, G.; Cambi, G.; Bruni, F.; Selleri, S.; Melani, F.; Montali, M.; Martini, C.; Ghelardini, C.; Norcini, M.; et al. Novel 3-aroylpyrazolo[5,1-c][1,2,4]benzotriazine 5-oxides 8-substituted, ligands at GABAA/benzodiazepine receptor complex: Synthesis, pharmacological and molecular modeling studies. Bioorg. Med. Chem. 2008, 16, 4471-4489. [CrossRef] [PubMed]

25. Penning, T.D.; Thomas, S.A.; Hajduk, P.J.; Sauer, D.R.; Sarris, K.; Giranda, V.L. Potent PARP Inhibitors. WO 2007149907 A2, 27 December 2007.

26. Wongsamitkul, N.; Maldifassi, M.C.; Simeone, X.; Baur, R.; Ernst, M.; Sigel, E. $\alpha$ subunits in GABAA receptors are dispensable for GABA and diazepam action. Sci. Rep. 2017, 7, 15498. [CrossRef] [PubMed]

27. Maldifassi, M.C.; Baur, R.; Sigel, E. Molecular mode of action of CGS 9895 at $\alpha 1 \beta 2 \gamma 2$ GABAAreceptors. J. Neurochem. 2016, 3, 722-730. [CrossRef] [PubMed]

28. Martini, C.; Lucacchini, A.; Ronca, G.; Hrelia, S.; Rossi, C.A. Isolation of Putative Benzodiazepine Receptors from Rat Brain Membranes by Affinity Chromatography. J. Neurochem. 1982, 38, 15-19. [CrossRef]

29. Primofiore, G.; Da Settimo, F.; Taliani, S.; Marini, A.M.; Novellino, E.; Greco, G.; Lavecchia, A.; Besnard, F.; Trincavelli, L.; Costa, B.; et al. Novel N-(arylalkyl)indol-3-yl glyoxylylamides targeted as ligands of the benzodiazepine receptor: Synthesis, biological evaluation, and molecular modeling analysis of the structure activity relationships. J. Med. Chem. 2001, 44, 2286-2297. [CrossRef]

30. Lowry, O.H.; Rosenbrough, N.J.; Farr, A.L.; Randall, R.J. Protein measurement with the Folin. J. Biol. Chem. 1951, 193, 265-275. [CrossRef]

31. Cheng, Y.; Prusoff, W.H. Relation between the inhibiton constant (Ki) and the concentration of inhibitor which causes 50 percent inhibiton (IC50) of an enzymatic reaction. Biochem. Pharmacol. 1973, 22, 3099-3108. [CrossRef]

32. Colman, A. Transcription and Translation: A Practical Approach; Hames, B.D., Higgins, S.J., Eds.; Oxford University Press: Washington, DC, USA, 1984; ISBN 9780904147520.

(C) 2019 by the authors. Licensee MDPI, Basel, Switzerland. This article is an open access article distributed under the terms and conditions of the Creative Commons Attribution (CC BY) license (http://creativecommons.org/licenses/by/4.0/). 